\section{A ARS BILDUMA \\ ISSN 1989-9262 \\ UPV/EHU Press \\ ARSBILDUMA (CC BY-NC-ND 4.0)}

https://doi.org/10.1387/ars-bilduma.22110 BIBLID [(2021), 11; 83-106]

Recibido: 08/09//2020 Aceptado: 19/09/2020

\section{MARÍA DEL MAR DÍAZ GONZÁLEZ}

Universidad de Oviedo

Facultad de Filosofía y Letras

Departamento de Historia del Arte y Musicología

Campus del Milán

33011 Oviedo (Asturias)

mdiazg@uniovi.es

https://orcid.org/0000-0003-0234-1493

\title{
LA PRODUCCIÓN XILOGRAFICA DE FRANS MASEREEL (1889-1972). ILUSTRACIONES, ESTAMPAS Y NOVELAS GRÁFICAS AL SERVICIO DEL COMPROMISO SOCIAL
}

THE PRODUCTION WOODBLOCK OF FRANS MASEREEL (1889-1972). ILLUSTRATIONS, PRINTS AND GRAPHICAL NOVELS TO THE SERVICE OF THE SOCIAL COMMITMENT

LA PRODUCTION XYLOGRAPHIQUE DE FRANS MASEREEL (1889-1972). ILLUSTRATIONS, ESTAMPES ET LIVRES EN IMAGES AU SERVICE DE SON ENGAGEMENT SOCIAL

RESUMEN

La contribución de Frans Masereel a la renovación del lenguaje vanguardista es trascendente. La unidad de su discurso plástico ampara su evolución en los diversos procedimientos cultivados. El artista belga supera las expectativas despertadas por los expresionistas alemanes del primer cuarto del siglo XX. Desde las fuentes documentales hemerográficas e historiográficas, se analiza la trayectoria del xilógrafo y su destierro, fruto de su compromiso pacifista. Tampoco se elude su credo social, atestiguado en las obras concebidas durante su extenso periodo de actividad.

PALABRAS CLAVE

Masereel; xilografía; narrativa; ilustración arte; literatura; novela gráfica; estampa.
ABSTRACT

Frans Masereel's contribution to the renewal of avant-garde language is transcendent The unity of his plastic discourse protects his evolution in the various cultivated procedures. The Belgian artist exceed the expectations aroused by the German Expressionists of the first quarter of the 20th century. From the hemerographic and historiographic documentary sources, the trajectory of the xylographer and his exile, the fruit of his pacifist commitment is analyzed. His social creed, attested in the works conceived during his extensive period of activity, is not eluded either.

KEYWORDS

Masereel; woodcut; narrative; illustration art; literature; graphic novel; print.
RÉSUMÉ

La contribution de Frans Masereel au renouveau du langage d'avant-garde est transcendante. L'unité de son discours plastique réfracte son évolution dans les différents procédés cultivés. L'artiste belge surpasse les convoitises suscitées par les expressionnistes allemands du premier quart du XXe siècle. A partir de sources documentaires hémérographiques et historiographiques, la trajectoire du xylographe et de son exil, fruit de son engagement pacifiste, est analysée. Son credo social, affirmé dans les œuvres conçues pendant sa longue période d'activité, n'est pas non plus éludé.

MOTS-CLÉS

Masereel; gravure sur bois; narration; illustration; art; littérature; roman graphique; estampe. 


\section{INTRODUCCIÓN}

En términos expositivos y bibliográficos, el reconocimiento mundial de Frans Masereel (Blankenberge, 1889-Aviñón, 1972) no encuentra falla alguna. Sin embargo, se podría tildar su difusión en España de más bien discreta y, en algún sentido, incluso desdibujada. En efecto, la temprana presencia del xilógrafo belga en nuestro país estaría relacionada con la invitación cursada por el gobierno de la República Española en 1937¹. Junto con una delegación de pintores parisinos, involucrada en los preparativos de la Exposición Internacional, Masereel habría visitado Barcelona, Madrid y Alicante. La hipótesis, plausible sin duda, no puede verificarse, ya que ninguno de sus biógrafos la documenta, si bien es cierto que todas las fuentes historiográficas consultadas la mencionan. Tampoco existe constancia alguna de muestras de sus obras anteriores a la modesta selección que, en colaboración con el Frans Masereel Centrum, fue promovida por "Sa Nostra" de Caixa de Balears en 1995². Un año después, Caja de Ahorros de Asturias exhibe en sus galerías una colectiva de estampas de diversos artistas internacionales en el mencionado centro de Kasterlee (Bélgica) sin presentar en aquella ocasión, ninguna obra del xilógrafo ${ }^{3}$. En 2000 quien suscribe este artículo organiza una retrospectiva del autor flamenco en la primera planta del Centro Cultural Cajastur Palacio Revillagigedo de Gijón.

En cambio, las actualmente denominadas novelas gráficas de Masereel suscitan mayor interés entre los editores españoles. En 1990, la firma Muchnik publica su espléndido Libro de horas y aparece bajo su usual denominación, Viaje apasionado. Reproduce el

1 Roger Avermaete lo afirma sin acreditar las fuentes documentales relativas a su viaje a nuestro país y dada la estrecha relación que les unía, esa posibilidad es factible A partir de esta indicación los demas autores que han tratado qu figura mencionan esta visita a Espana En cambio sí existe constancia de la

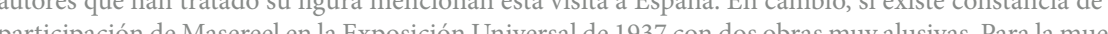
participación de Masee tra Arts et techniques de París aporta Leenterrement de la guerre y en el pabellón belga cuelga La lecture actualmente en la Biblioteca Pública de Amberes. Véase AVERMAETE, R.: Frans Masereel. Amberes, Fonds Mercador, 1975, pp. 50-52 y 56-59.

2 Junto con una selección de obras del xilógrafo belga, se exhibe asimismo una colectiva de artistas internacionales que habían pasado por el centro. Véase AA.VV.: Frans Masereel Centrum. Obra Gràfica. Baleares, Ministerie van de Vlaamse Gemeenschap y Caixa Balears, 1995.

3 DÍAZ GONZÁLEZ, M. M.: Obra gráfica, Frans Masereel Centrum. Oviedo, Caja de Ahorros de Asturias, Obra Social y Cultural, 1996. En 1989, el artista litógrafo asturiano Francisco Velasco es el primer español invitado a desarrollar una estancia en el centro de Kasterlee, revalidando periódicamente durante 13 años consecutivos esta interesante experiencia creativa.

4 DÍAZ GONZÁLEZ, M. M.: Frans Masereel. Oviedo, Cajastur, Obra Social y Cultural, 2000. prólogo original de Thomas Mann (1919) y las 167 xilografías de pequeño formato. Más adelante, la Editorial Iralka imprime La Idea, incorporando la dedicatoria de Hermann Hesse para la edición alemana de 1927. Esta serie gráfica surge en 1920 y confirma una de las características más paradigmáticas de las creaciones del artista flamenco como es el relato autobiográfico. En 2012, Nórdica Libros da a la prensa La Ciudad, obra magna y excepcional que influye profundamente en el cómic franco-belga y, probablemente, en la mayor parte de los comiqueros internacionales. Para el primer volumen original, el artista talla un centenar de tacos en 1925 y, a partir de esta primera entrega, surge una reedición en 1928. El éxito de este relato en imágenes lo sitúa ciertamente en la cúspide del género y también lo consagra como un gran maestro de la xilografía.

El volumen de reseñas, noticias y artículos se incrementa mucho en estos momentos, lo que corrobora el alcance actual del grabador belga. En 2000, el investigador sólo disponía de escasas menciones en obras españolas de consulta general. En el mejor de los casos, su nombre integraba la extensa nómina de artistas de las primeras vanguardias internacionales y, como mucho, una sucinta reseña en la historiografía especializada en obra gráfica contemporánea.

Sus creaciones se circunscriben siempre a los movimientos artísticos más relevantes del primer tercio del siglo XX. Determinados críticos e historiadores lo sitúan, no sin razón, en la nutrida nómina de la Escuela de París, lo cual no aclara nada respecto de su línea de trabajo. Si la potencia de sus imágenes entronca con el expresionismo alemán de Die $B r u ̈ c k e^{5}$, la diversidad de su legado artístico y su preponderancia narrativa dificultan una adscripción en sentido estricto. En lo personal, Masereel acredita un carácter muy sólido, sustentado por valores éticos incontrovertibles. Prevalece su sentido de la libertad, su compromiso político y su voluntad de independencia.

Los acontecimientos trágicos lastran su trayectoria vital y afloran en sus creaciones artísticas atestiguadas por hechos atroces e incomprensibles . La Gran Guerra es el preámbulo de su alegoría dramática y logra su paroxismo en la segunda contienda mundial. Sus primeras

5 Se sitúa su producción dentro de la escuela expresionista flamenca, influenciada a su vez por las aportaciones de los alemes Pechstein, Schmidt-Rottluff, Kirchner o Nolde. En cambio, otros historiado 1963, pp. 341-344.

6 VAN DEN BOSSCHE, O.: “Frans Masereel (1889-1972): idéalisme dans lart d'un témoin del'histoire", Arts ê Sociétés, n. ${ }^{4} 42,2012$. http://www.sciencespo.fr/artsetsocietes/fr/archives/1694 [Consultado el 04/08/2019]. 
ilustraciones en prensa espejean su propia lucha personal frente al ominoso ajuste de cuentas entre las naciones capitalistas. Por otra parte, su compromiso pacifista implica igualmente su deserción del ejército belga. Hasta 1928, no se regulariza su situación, pero persiste su recelo durante muchos años, como así lo expresa el propio autor?

La preparación del mencionado evento expositivo ha requerido un estudio de la trayectoria y de la obra del artista. La consulta inexcusable de los fondos documentales, archivos y museos belgas que custodian su memoria resultó fatigosa y compleja debido al idioma neerlandés ${ }^{8}$. A ello, se añaden las fuentes hemerográficas depositadas en el centro flamenco de Kasterlee y su epistolario, venero imprescindible para el abordaje de la muestra y también de este artículo. A partir de aquella primera aproximación, se ha tenido la ocasión de profundizar bastante en el conocimiento de su trabajo, cimentado ahora en recientes investigaciones más actualizadas que justifican este nuevo texto.

\section{EL RETO DE LA PAZ EN LA GUERRA: APUNTE BIOGRÁFICO}

En su ciudad natal de Blankenberge, el pequeño Frans observaba durante el estío las faenas de los pescadores con auténtica devoción ${ }^{9}$. Este espectáculo vital cotidiano, al igual que el susurro del viento y el manto invisible del salitre, forjaron su inquebrantable personalidad. Durante su vida adulta, la mar es su arcadia personal y, paradójicamente, también su único refugio en las horas más desesperanzadas. Su adolescencia y juventud transcurren en Gante, donde ingresa en la Academia de Bellas Artes. Auspiciado por su profesor Jean Delvin (Gante, 1853-1922) ${ }^{10}$, sustenta su formación sobre el dibujo, pilar fundamental de

7 "Outre mes parents, je serai content de revoir les petites villes de la campagne des Flandres. Mais les Belges? Je m’en fous complètement. Moi non plus je noublie pas certaines choses, et vous savez que la fibre patriotique chez moi est inexistante". Extracto de una carta enviada por Masereel a Romain Rolland. En AVERMAETE, R.: Op. cit., epígrafe «Évolution», pp. 34-36. El resentimiento no cesó y, aún en la década de 1960, el ministro Leo Tindemans desconfía respecto de su figura. Véase al respecto BRACKE, E. "Jorijs Van Parys over zijn Frans Masereel-biografíe". Diario De Morgen, 28 de abril de 1995 y BRACKE, E.: "Frans Masereel, een onvergeteliike kunstenaar". Doen - (Stad-Antwerpen), enero de 1997.

8 Frans Masereel pertenecía a la burguesía flamenca francófila y francófona y así se advierte en su correspondencia y en el título de sus estampas, casi siempre en francés. Actualmente, se detecta una reivindicación nacionalista de su figura y de su obra, lo que explica el incremento de la bibliografía en neerlandés, en la que se omiten lo más posible los términos galos.

9 VAN PARIJS, J.: Masereel, een biografie. Amberes: Houtekiet, 1995, pp. 11-39. su creación artística desde su más tierna infancia. Tras un periodo de dudas respecto a su primera vocación, el artista se decanta por la creación artística. Por tradición familiar, le interesa la música, pero también la literatura y la plástica, vía creativa a la que finalmente se consagra con absoluta pasión.

En 1908, Masereel visita Londres, más adelante se va a Alemania, Holanda y Túnez, antes de asentarse finalmente en París. Las circunstancias sociopolíticas le otorgan pronto la ocasión de emplear su producción artística como un medio de denuncia y de expresión, no reconociendo tampoco préstamos estilísticos de ningún otro artista ${ }^{11}$. Con el estallido de la Primera Guerra Mundial, se niega a incorporarse a filas y es declarado prófugo en Bélgica, regularizando su situación por intercesión del arquitecto y pintor Henry van de Velde ${ }^{12}$

10 Jean Delvin asumió la dirección de la Academia de Gante de 1902 a 1922, donde se había formado la Escuela Expresionista Flamenca de Laethem-Saint-Martin (George Minne, Gustave y León De Smet, Frits Van den Berghe, Constant Permeke, Albert Servaes, Jan y Josef Cantré y Jules de Bruycker). Delvin fue miembro fundador del grupo Les XX, consolidado en Bruselas en 1883, con la participación de los pintores Guillaume Van Strijdonck, Constantin Meunier y Darío de Regoyos (Ribadesella, 1857-Barcelona 1913). Véanse HOOZEE, R.: Tekeningen, pastels en aquarellen uit eigen collectie. Gante, Catálogo General de Fondos del Museum voor Schone Kunsten, 1985 y BARÓN TAHIDIGSMANN, J.; MORALES MATOS, G.: Arte y Sociedad en Bélgica. 1848-1914, Oviedo, Museo de Bellas Artes de Asturias, 1985. Para más información sobre el primer periodo de Masereel se recomienda el artículo de HOOZEE, R. VANFLETEREN, H.: Frans Masereel. Frans Masereel Centrum, Obra gràfica. Baleares, Ministerie van de Vlaamse Gemeenchap, Caixa de Balears, 1994, pp. 13-17.

11 En el prólogo del catálogo de la retrospectiva organizada en Niza en 1965, Masereel afirma: "Dans mon travail, je me suis laissé guider, avant tout, par mon expérience de la vie. Cela a été pour moi la véritable cource ou '? subi des «influences», car c’est d'après la nature que je dessine" Citado por AVERMAETE, R. Op cit, p. 12 , recoge sus palabras.

2 Véase el interesante artículo de TONDEUR, M.: "Des hommes contre, 1914-1918: artistes et écrivains contre la guerre". Revue d' Études marxistes, n. ${ }^{\circ} 110,2015$ http://www.marx.be/fr/content/\%C3\%A9tudes-marxistes-no-110 [Consultado el 01/08/2018]. El autor de este texto estudia la vertiente del pacifismo como un medio activo de oposición a la Primera Guerra Mundial, considerada como un conflicto de intereses entre diversas potencias. Bélgica asume el conflicto en clave nacionalista y con afán patriótico, castigando duramente las facciones díscolas, declarando prófugos a los muchachos que

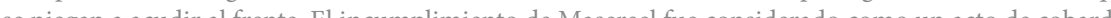
y reprobado durante mucho tiempo. Legaiza ciertamente su situacon, pero no es ni bien recibido n aplaudido hasta finales de la década de 1950. Incluso, los partidos flamencos ultraconservadores aún execran su figura, considerada antipatriótica y comunista. 
Se asienta primero en la neutral Ginebra, al igual que otros artistas e intelectuales allí concitados en 1916. Amparado por el literato francés Romain Rolland, sella su compromiso con los grupos pacifistas y se adhiere a la Cruz Roja. Sus primeras creaciones artísticas transidas de sentimiento crítico, y su condena a la guerra, indisponen aún más a las autoridades belgas. Concentrado en su actividad y espoleado por sus convicciones antibélicas, el artista asume el destierro con indiferencia. Al término del conflicto, la mayor parte de sus amigos regresan a sus países de origen y Masereel experimenta entonces el rigor de su aislamiento. Toma la arriesgada decisión de viajar errante e indocumentado a Francia.

En 1922, se instala en París donde restaña sus lazos de amistad con artistas y escritores ${ }^{13}$ A tenor de las numerosas muestras realizadas en aquellos momentos, se colige una intensa actividad que no menoscaba su nostalgia de Flandes. Con el fin de atenuar su desazón, sus familiares y amigos más cercanos promueven el traslado de una embarcación: "De Kievit" El medio marino le retrotrae a sus vivencias infantiles, y muchas de sus creaciones (óleos y acuarelas) imbrican sus asuntos en los embarcaderos y en los puertos marítimos. Souvenirs Marins, 1936; Navires, 1937; La Mer, 1938 o La Nature, 1939, son algunos ejemplos. Pas-deCalais es de nuevo su ámbito de conexión con la mar y con la naturaleza. En 1925, adquiere en Equihem el taller artístico de los hermanos Charles y Michel Cazin para convertirlo en vivienda y estudio. Junto a sus amigos Stefan Zweig y Georg Grosz, disfruta allí de intensos periodos de trabajo

En 1926, con motivo de una muestra de sus creaciones en el Museo de Arte Moderno Occidental de Moscú, viaja a la antigua Unión Soviética por primera vez. El dramaturgo ruso y comisario cultural Anatoli Lunatcharski prologa el catálogo de su exposición. Obtiene otro visado en $1935^{15}$, cuando arrecian vientos de guerra en Europa. Hitler asume

13 Masereel rehuye las tertulias artísticas, estrechando amistad con Henri Le Fauconnier, Luis Bouquet con los artistas de la galería parisina de Joseph Billiet. En 1924, conoce a Georg Grosz y, hasta que el berlinés se marcha a Estados Unidos, comparten algunos ideales. Trata asiduamente a Picasso durant sus estancias en Aviñón, Antibes y Niza y, al parecer, nunca hablaban ni de técnica ni de estética. En el extracto de su correspondencia en AVERMAETE, R. Op. cit., p. 59, se recogen sus opiniones al respecto: "Sur la demande des Syndicats de la Région Parisienne jai organisé un cercle ouvrier de dessin et de peinture. (...) Le contact avec ces bougres-là est autrement sain et réconfortant qu’avec les intellectuels qui me font suer de plus en plus".

14 La traducción literal De Kievit se refiere al avefría. Es evidente que la simbólica del término remite a su origen nórdico, a su condición migratoria y a su acendrado sentido de la libertad.

5 Cuando Masereel recala en Ginebra en 1916, entra en contacto con los círculos pacifistas abanderados el poder gubernamental y militar en 1934 y, desgraciadamente, España gesta el preámbulo de una desgarradora Guerra Civil. En la U.R.R.S.S., Masereel siente la esperanza de un cambio social, pero la barrera del idioma frena su entusiasmo, por lo que trata de aprender ruso en $1936^{16}$. Sus cuadernos de viajes atestiguan numerosas vistas a Moscú y a otras ciudades. Entre sus apuntes, aparece Máximo Gorki (Novgorod, 1868-1936) sobre el catafalco. Este tributo al fundador del realismo literario en Rusia acredita una vez más la pasión de Masereel por la narrativa.

Sumando el compromiso político y el interés profesional, también visita China en 1958 con motivo de otra de sus exposiciones. Allí comprueba muy sorprendido el calado de su influencia sobre algunos artistas orientales. Antes de su desplazamiento, la Galerie Billiet organiza en París una muestra de xilografías chinas contemporáneas en las que las filiaciones del flamenco son indiscutibles. En un relato autobiográfico, el escritor Lu Xun (1881-1936) comenta su formación en Japón donde puede ver obras de grabadores europeos, entre los cuales Masereel. También adquiere dos álbumes del artista flamenco, 25 Images de la passion d'un homme (1918) y Mon livre d'heures (1919). Cuando el literato regresa de nuevo a su país, promueve talleres de xilografía para reivindicar la tradición milenaria de esta técnica y, sin saberlo, Masereel es el referente de las iniciativas de Lu Xun en China y, de ahí, su influencia en los artistas orientales ${ }^{17}$.

Durante la Segunda Guerra Mundial, su refugio en Pas-de-Calais es incautado por la artillería alemana que instala una plataforma ofensiva contra Gran Bretaña. En 1940, el poblado pesquero y el estudio de Masereel en Equihem sufren los bombardeos de la aviación germana. Una vez más, su nostalgia le impele a afincarse en Niza donde adquiere, en 1949, una vivienda frente al puerto. Tras sus segundas nupcias con Laure Malclès, el artista disfruta largas temporadas en Aviñón, falleciendo allí el 3 de enero 1972.

por Romain Roland. Conoce a intelectuales rusos tales como Biroukoff (biógrafo de Tolstoï), Gontcharov, Zelenine y Lunatscharski (1875-1933), Comisario de Educación desde 1918. Masereel expone varias veces en la antigua Unión de Repúblicas Socialistas Soviéticas y, más adelante, en China (1958) En VAN PARIJS, J.: "Frans Masereel in Moskou". Nieuw Wereldtijdschrift, 1994, pp. 4-11; y HEARD HAMILTON, G. Pintura y escultura en Europa, 1880/1940. Madrid, Cátedra, 1980, pp. 317-332.

16 Archivos del Frans Masereel Centrum, Kasterlee, Bélgica. Consultar a este respecto el artículo de DECKER, J.: "La traversée du siècle de Masereel". Diario Le Soir, lunes de 15 enero de 1996.

17 Más información en VAN NIEUWENBORGH, M.: "Masereel is in China ongewoon aktueel". Diario Standaard, 27 de agosto 1989 
En 1950, su categoría artística se consolida con el Gran Premio Internacional de Grabado de la Bienal de Venecia. Siguen otras muchas distinciones, cargos honoríficos y homenajes entrañables en su país natal y fuera de él. Tras muchas tensiones, Bélgica le otorga su reconocimiento, representándola en las colectivas internacionales más importantes: Les Peintres et Graveurs Belges Contemporains (1947, Museo de Pintura de Burdeos), LAArt Belge de 1910 à 1950 (1952, Kunsthalle de Bâle), L’Art Belge de la fin du XIXème siècle et du XXème siècle (1956, Museo Pouchkine de Moscú), L'Expressionisme flamand en Art Graphique (1962, Librairie La Proue de Bruselas) o en las exposiciones dedicadas al grupo Les Cinq, como la del Museo Estatal de Berlín, de 1968.

\section{FLANDES: PUNTO DE PARTIDA Y DE RETORNO}

Por influencia de Jules De Bruycker (Gante, 1870-1945) ${ }^{18}$, profesor de Frans en la Academia de Bellas Artes, la predestinación es uno de los conceptos recurrentes dentro de las reflexiones del xilógrafo. Otro legado de su maestro De Bruycker, se afianza sobre el dibujo, como medio de expresión emocional. Ambos artistas se habían formado en la misma institución académica de Gante, siendo discípulos de Théodore Canneel y de Jean Delvin. La diferencia de edad entre ellos no empaña nunca su sólida amistad, atestiguada de facto en las creaciones del xilógrafo, cuyos préstamos estilísticos remiten indudablemente al gantés De Bruycker. El Autorretrato a lápiz realizado por Masereel en 1909 resulta un buen ejemplo. Los resabios modernistas de este trabajo no mitigan la delicadeza del trazo preciso y ajustado, similar al de su admirado profesor. Además, entre otras deudas de reconocimiento, Masereel confirma la educación de la mirada, recurso inestimable para afrontar su aprendizaje personal. En el mismo contexto, descubre la miseria lacerante de los suburbios de Gante y se confronta a una realidad desconocida, ajena por supuesto a su ambiente familiar burgués.

18 Además de pintor y dibujante talentoso, Jules De Bruycker también domina el procedimiento calcográfico. Sus temas se centran en las clases más depauperadas de la ciudad de Gante. Durante la Primera Guerra Mundial se exilia a Londres dibujando allí escenas bélicas en la línea de El Bosco y de Brueghel. A su regreso, se decanta a Lor cost dbrismo de Gonte Su sentido de la monumentalidady la elegana

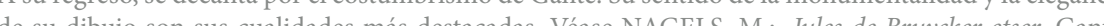
de su dibujo son sus cualidades más destacadas. Vease NAGLLs, M... Jules de Bruycker etser. Gante, Museum voor Schone Kunsten, Inventario de la obra sobre papel del Museum voor Schone Kunsten de Gent, 1995, pp. 107-110
La producción artística más reciente, en concreto la de las décadas de 1950 y 1960, delata su nostalgia de Flandes y, a ese respecto, citamos el boceto acuarelado relativo a la actividad portuaria del río Escalda (Escaut/Schelde, 1958) y una vista del Hôtel Osterrieth, 1955, su particular homenaje a la próspera ciudad comercial de Amberes.

En 1959, tributa su reconocimiento a dos grandes maestros belgas a quienes dedica dos matrices extraordinarias: Hommage à Brueghel ${ }^{19} \mathrm{y}$ Hommage à Rubens ${ }^{20}$. No obstante, edita previamente un Hommage a Verhaeren, el gran poeta flamenco que encabeza, junto con Maurice Maeterlinck, la corriente literaria simbolista belga ${ }^{21}$. En 1917, Masereel consagra 57 matrices al poemario Quinze poèmes y, en 1920, 28 tacos al volumen Cinq Récits, donde incorpora un retrato póstumo de Verhaeren ${ }^{22}$. En los numerosos retratos de sus amigos, el xilógrafo les prodiga siempre su afecto y sentido de la amistad. La incompatibilidad entre literatos y artistas plásticos tampoco socava su afecto por los escritores y prueba, de ello, es el elenco de efigies a ellos dedicadas ${ }^{23}$

Antes de su diáspora, Masereel forja los cimientos de su personalidad en un país de larga tradición impresora ${ }^{24}$. Paradójicamente, no aprende la técnica xilográfica en Flandes, sino en París y tras su regreso de Túnez en 1912. Aconsejado por Quatreboeufs, un proveedor

19 Desde su formación en Amberes en el taller de Pierre Coecke (c.1550) y más tarde en el de Jerôme Cock, Pieter Brueghel (Campine, c. 1525-Bruselas, 1569) encabeza una saga familiar de artistas flamencos. Brueghel se solidariza con los dramas de su tiempo, convirtiendo los motivos de sus obras en un verdadera reflexión sobre el destino

20 La pintura de Pedro Pablo Rubens (Siegen, Westfalia, 1577-Amberes, 1640) es una exaltación de vida expresada por medio de un frenesí de formas y de colores de exuberante resonancia.

21 Tras una crisis espiritual muy aguda, la obra del literato, poeta y crítico Émile Verhaeren (Amands Amberes, 1855-1916) evoluciona del naturalismo al misticismo. Visita España junto a Darí de Regoyos y la revista L'Art Modeme publica esta experencia ilustrada por Regoyos. La elicín espano la rrespondance, n. ${ }^{\circ}$ 3, octubre 1993. Consultar igualmente VERHAEREN, É.; REGOYOS, D. de: España Negra. Madrid, Taurus Ediciones, 1963

22 VERHAEREN, E.: Cinq récits ilustrés de bois de Masereel. Bruselas, Le vice impuni, Editorial Jacques Antoine, 1985.

23 En 1927, el xilógrafo explica a Romain Rolland su malestar con respecto a las ilustraciones iniciadas en 1925 para los cinco tomos del libro Jean-Christophe: "Je n’ai jamais montré mes dessins à l'auteur d'un livre dans un but critique ni d’pprobation, avant de les graver; et si cela à pu arriver par hasard je men

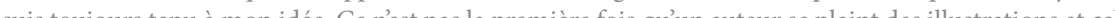
renforce la conviction que jai: incompatibilite totale entre lecrivain et le plasticien. En AVERMAETE, R.: Op. cit., pp. $36-40$.

24 Esta tradición se remonta al siglo XVI, con precedentes tan significativos en Europa como Planti 
de material artístico, decide adentrarse en esta práctica. Avermaete resalta su pasión juveni por el coleccionismo de estampas antiguas, imágenes devocionales, naipes, impresiones tabularias y ediciones de bibliófilo. En restrospectiva, la creación titulada Le valet de coeur, 1948, confirma su interés por los ephemera.

La ambición expresiva del autor encuentra su mejor acomodo en el grabado en relieve y al igual que Die Brücke, admira el sustrato popular de esta técnica antigua. Su dominio y maestría lo sitúan en el primer rango de la escuela flamenca, que cuenta con otros cuatro artistas más. Junto con Henri van Straten (Amberes, 1892-1944), Joris Minne (Ostende, 1897-Amberes 1988), Jan Frans Cantré (Gante, 1886-1931) y Jozef Cantré (Gante, 18901957), Masereel integra el grupo Les Cinq, en neerlandés De Vijf. En 1919, realizan las ilustraciones de la revista Lumière, editada en Amberes por Roger Avermaete ${ }^{25}$. La cercanía estilística de todos ellos determina a posteriori la designación forzada del grupo, avalado asimismo por numerosas colectivas. A partir de esta unidad formal se justifica una cohesión grupal que nunca fue tal. Ciertamente, el talento de Masereel destaca sobre el resto y, por otra parte, el xilógrafo crea sus obras al margen de los demás miembros. No debemo olvidar que, hasta 1928, vive su destierro en Francia, donde permanece toda su vida, no compartiendo con los otros artistas más que esporádicos encuentros.

La renovación estética xilográfica, como técnica singularmente vanguardista, impregna toda su trayectoria. Con razón, su producción despunta por su originalidad dentro del panorama artístico de la primera mitad del siglo XX. En comparación con el bronco expresionismo de los alemanes, el estilo de Masereel desprende una gran armonía y está dotado asimismo de una vibrante y personal energía (Fig.1)

Moretus (Saint Avertin, 1520-Amberes, 1589). Durante el primer cuarto del siglo XIX, eclosiona la industria de los naipes en la ciudad de Turnhout. La producción se efectúa primero mediante el grabado en relieve y/o en hueco, posteriormente se imprimen por el método litográfico. Los naipes belgas entran en competencia con los de Heraclio Fournier en España. Las industrias de Turnhout se agrupan en 1970 bajo la denominación Carta Mundi. En VAN AUTENBOER, E.: "La industria de los naipes de Turnhout (1826-1976)”. Noticias de Bélgica, n. ${ }^{\circ}$ 166. Bruselas, Ministerio de Asuntos extranjeros, 1976 pp. 144-145.

25 Para más información sobre el grupo Les Cinq véanse GYSELEN, G.: "La gravure sur bois et sur linoléum en Flandre à l'époque de la Grande Guerre" Revue de Culture Néerlandinse. Septentrion, 1/84, 13 e Anné 1984, pp. 17-24, HOUWBN, H. "De Bethenis van Brans Mareet A de septienbre de 1993. Tamben restlan pertinentes los siguientes attchlos DOSOGNE, L.: "H geweld van zwart en wit". Diario De Morgen, 17 de julio de 1997. MIN, E.: "Artiesten kerven hun ziel in hout voor "Lumière". Gazet van Antwerpen, 10 de julio de 1997; HOLSBEEK, D.: "Meesters houtsni-

\section{LA PRODUCCION DE MASEREEL}

El impacto de la Primera Guerra Mundial determina la orientación de su concepción artística inicial y encauza su trayectoria estética posterior, gobernada siempre por los negros más profundos como recurso de expresión y razón de estilo. Aunque no toma parte activa en el conflicto, sí se implica en los acontecimientos ${ }^{26}$. Desde esta perspectiva, encauza su propia lucha personal en el movimiento pacifista de Ginebra y encabeza allí un frente de combate gráfico y dialéctico de inusitada mordacidad.

La historia de la civilización demuestra sin cesar que la guerra es una pulsión destructiva consustancial a la naturaleza humana y los periodos de paz no suponen, de hecho, más que un breve interludio entre peleas y combates sangrientos. Desde la antigüedad más tardía el asunto bélico protagoniza muchas composiciones artísticas. Los conflictos son evocados desde todos los géneros posibles e invaden toda clase de soportes. Las luchas, reales o ficticias, forman parte del imaginario colectivo que integra su teatral grandilocuencia. La arquitectura clásica es la depositaria de algunas creaciones artísticas pensadas para la eternidad, tales como las Amazonomaquias del Mausoleo de Halicarnaso (355-330 A.C.) y las Gigantomaquias (197-159 A.C.) del Altar de Zeus.

Como advierten las gestas heroicas y triunfantes, la guerra insaciable devora sin cesar porciones de vidas. Paolo Uccello (Batalla de San Egidio) y Rubens (Batalla de las Amazonas) glorifican algunas gestas cruentas. Por el contrario, al situar su mirada sobre las víctimas en La masacre de los inocentes y en El triunfo de la muerte, Brueghel ofrece un punto de vista más doloroso. Jacques Callot (Nancy, c.1590-1635) aporta una reflexión de mayor compromiso político: Misères et malheurs de la guerre ${ }^{27}$. En España, la Guerra de la Independencia (1808-1814) azuza la imaginación de Goya. El aragonés denuncia la

jkunst”. Diario De Standaard, 24 de julio de 1997. Se recomienda asimismo la obra de BITSCH, M.T. Histoire de Bélgique. París, Hatier, 1992, pp. 149-164.

26 Las palabras del artista son a este respecto muy esclarecedoras: "Les deux guerres mondiales ont été désastreuses pour moi, matériellement. Il serait trop long et inutile dentrer dans les détails. C'est le passe et je regarde plus volontiers vers lavenir. Moralement, jen ai beaucoup souffert aussi et cette souffrance a probablement aiguisé mon instinct combatif pour essayer de dévoiler les horreurs de cette monstruosité quest la guerre" en BUYENS, F. Frans Masereel, Ik hou van zwart ér wit. Films Lyda Dacapo 1969 (fimacion de 42 ming $y$ BUYBNS, F. Frans Maserel, Aspecten wan zijn werk. Filns Lyda (1980 (fil 1980 (filmación de 60 minutos). Varios documentales en rtbf.be, https://www.rtbf.be/culture/arts/detail_frans-masereel-images-de-resistance?id=9651551 [Consultado el 03/02/2020].

27 Sobre el citado grabador se recomienda la obra de BERSIER, J. E.: Op. cit., pp. 176-182. 


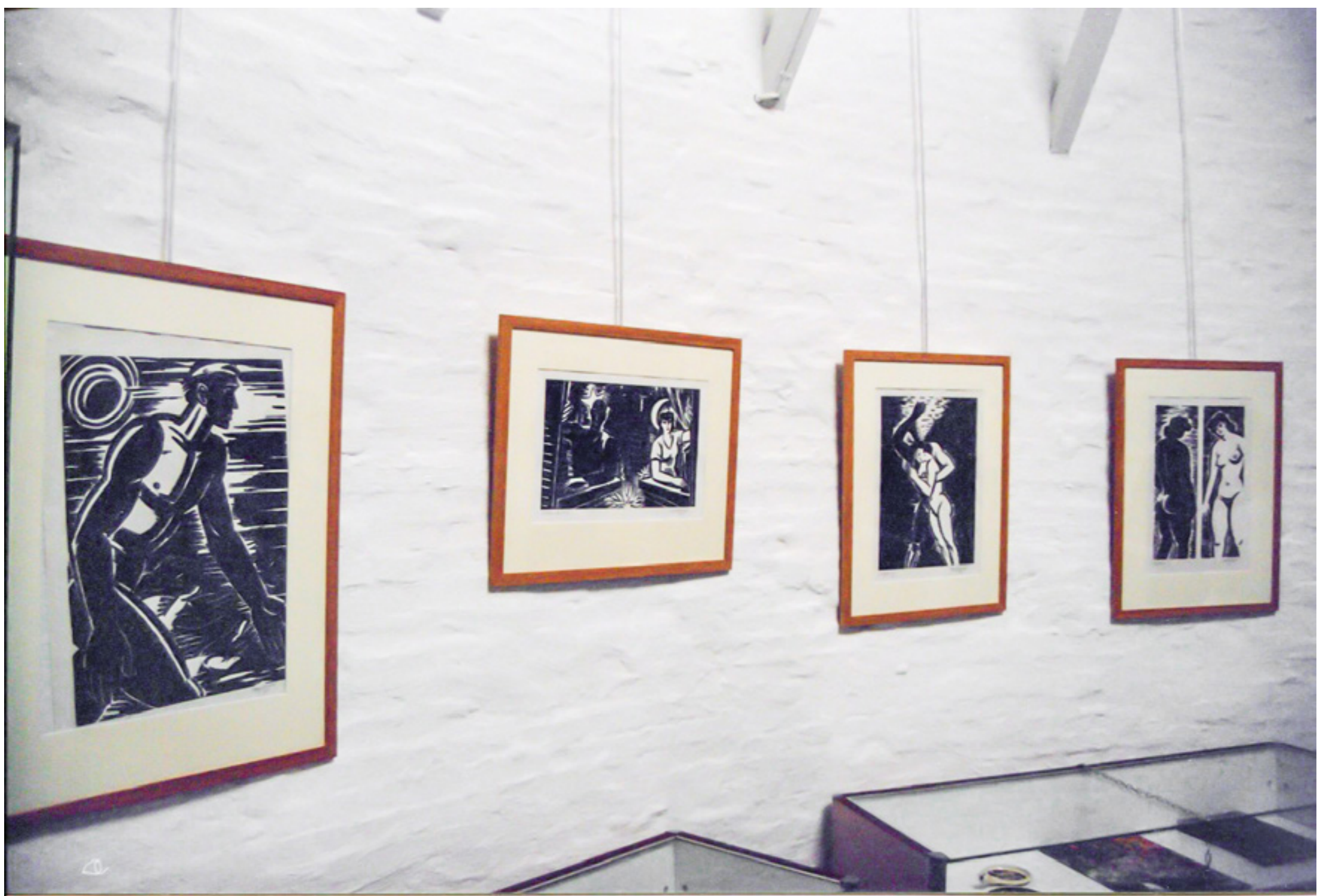

Fig. 1: L’homme qui marche, 1951; Voisins, 1951; Le couple, 1952; Beigneuse, 1953. Frans Masereel Centrum, Kasterlee, Bélgica, 1997. (Francisco Velasco) 
barbarie y la sinrazón mediante "un monumental grito contra la violencia en sus diferentes formas" 28 . La obra múltiple contribuye a la divulgación de los mensajes, convertidos en eco imparable. Lamentablemente, la horrenda imaginería bélica no cesa, dado que el ser humano no asume los estragos reflejados por artistas tan prolijos como Goya, Otto Dix, Ernst Ludwig Kirchner, Max Beckmann, Georg Grosz y tantos otros ${ }^{29}$.

La obra de Masereel se inscribe dentro de este crescendo creativo, protagonizado por el horror y por la violencia "patriótica" de la contienda. Sus primeras aportaciones se subordinan a la prensa periódica, publicando en los diarios y semanarios su crónica negra de inequívoco significado. Entiende que la guerra, esa en concreto, se afianza sobre la usura y el enriquecimiento de la clase política y de la burguesía bancaria e industrial. Al igual que otros artistas, toma partido por el hombre sometido, herido, vencido y abatido, y denuncia sus terribles padecimientos. Así representa a los pobres soldados de los frentes en contienda y, en cambio, satiriza inmisericorde una minoría avariciosa capaz de beneficiarse impunemente de aquella tragedia. El xilógrafo sitúa su mirada a ras de suelo, allí donde gimen y se retuercen los moribundos entre el vómito, las heces y la sangre y donde el miedo se funde con la nada.

\subsection{Ilustraciones en prensa periódica}

Como la afición de Masereel por el dibujo se remonta a su infancia, el legado de su maestro Jules De Bruycker contribuye a reforzar esta pasión durante toda su vida. En numerosas entrevistas declara haber iniciado su formación de manera intuitiva, cuando fue capaz de sostener un lápiz entre sus dedos. Existe un dibujo precoz consagrado a la Guerra de los Boers que Joris Van Parijs publica en la biografía del artista. A pesar de su esquematismo, este apunte reproduce detalles macabros descritos con precisión en la prensa periódica de aquella época. Los estandartes, las armas, los prisioneros encadenados y los muertos salpican toda la composición, como si se tratara de millares de hormigas en medio de un paisaje irreal ${ }^{30}$

28 En MATiLla, J. M.: "Imágenes del horror: de la comunicación a la reflexión". Estampas de la Guerra de la Independencia. Madrid, Museo Municipal de Madrid, Calcografía Nacional, Obra Social y Cultural de Caja de Ahorros de Asturias, 1996, pp. 13-16.

29 Es un tema extraordinariamente interesante, por lo que a propuesta mía la estudiante Beatriz Martínez López ha culminado su Grado de Historia del Arte con el trabajo La destrucción en el arte. Evolución y sintesis de las manifestaciones de la pintura vanguardista europea a través de los conflictos de la primera mitad del siglo XX, que obtuvo la máxima calificación en julio de 2017
En 1913, Masereel inserta ilustraciones y chistografías en diversas revistas satíricas belgas. Su primera actividad, conciliada con la caricatura y la historieta, pone de manifiesto su dominio de la línea y también su interés por el lenguaje verbal. Mediante la inclusión de una iconografía referencial, afronta la necesidad del relato a través de las imágenes. Las primeras aportaciones determinan su faceta de ilustrador y propenden, por ello, a la síntesis de línea y a la economía de los recursos plásticos. Además, la chistografía ${ }^{31}$ le impele a la concisión más absoluta en cuanto a la imagen y le induce al uso de textos de apoyo para explicitar el mensaje. La plancha del 17 de mayo de 1913, publicada en La Vie Illustrée, reúne todas estas cualidades. Cuatro viñetas independientes articulan la composición general, de la cual derivan dos unidades de lectura tituladas, Galanterie y Après le Congrès de Berne. La correlación temática se imbrica en la coyuntura sociopolítica de aquellos momentos y, mediante la sátira, Masereel potencia el sarcasmo de estos mensajes, relevantísimas fuentes de análisis socioculturales para el historiador.

Cuando Frans Masereel llega a Ginebra en 1916, comprueba la capacidad de transmisión de la prensa periódica y su inmenso poder de convocatoria. Junto con Claude Le Maguet, funda la revista Les Tablettes, editada con regularidad hasta 1919, logrando 48 números en total. El artista diseña planas, portadas, cabeceras e inserta algunas xilografías del álbum Debout les morts. En este sentido, la cubierta del número diez editado en julio de 1917 es modélica, por cuanto incorpora una de sus imágenes más dolorosas. La potencia visual despunta dentro del elenco de las numerosas cualidades de sus aportaciones. El icono de la portada justifica ampliamente esta rotunda afirmación. Un soldado inclina su torso hacia el lector, emitiendo al mismo tiempo un alarido desesperado: Assez! Proferido por medio de una caligrafía aristosa, este grito incrementa la expresividad de la imagen desencajada de muchacho. La eficacia de este detalle caligráfico contribuye a proyectar aún más el escorzo del protagonista hacia el espectador, sacudido por una representación desgarradora (Fig.2)

30 "Quel âge est-ce que j’avais? dix-douze ans, onze ans peut-être? A ce moment-là, javais commencé faire des dessins, des dessins d’enfant, bien sûr, contre la guerre et depuis je crois que j’ai continué à être très anti-guerrier" en AVERMAETE, R.: Op. cit. pp. 11-15. Véase igualmente VAN PARIJS, J.: Op. cit.

pp. 21-23.

ha sido utilizado por el crítico VILABELLA, J. M.: Humor gráfico asturiano. Oviedo, Ser-

31 vicio de Publicaciones, Caja de Ahorros de Asturias, 1987, para diferenciar la producción de chistes de la aportación historietística. 


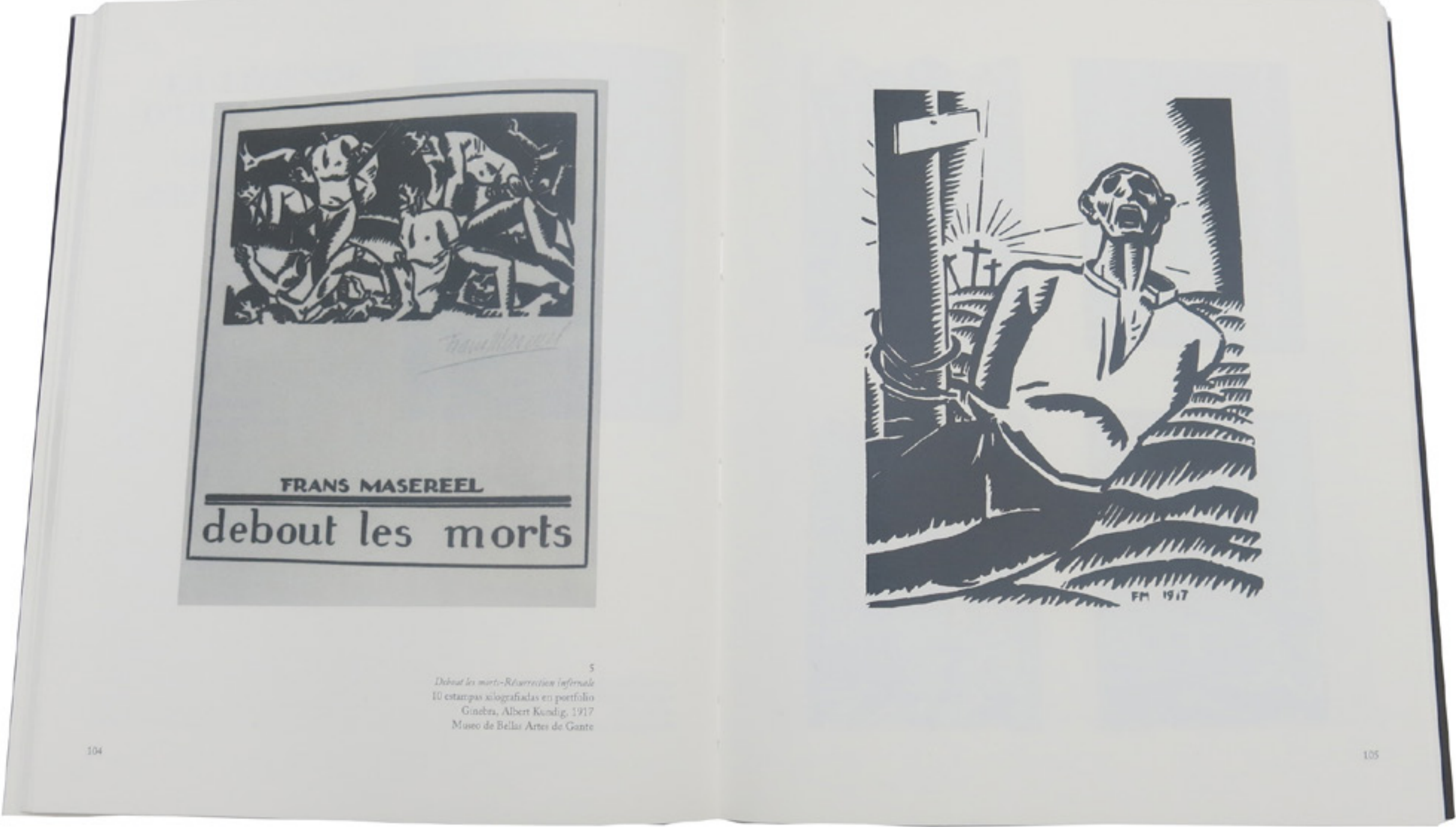

Fig. 2: Debout les morts-Résurrection infernale, estampas xilografiadas en portfolio, 1917 en Catálogo de la exposición Frans Masereel, mayo-junio de 2000, Centro Cultural Cajastur Palacio Revillagigedo, Gijón, pp. 104-105. Cortesía de Francisco Velasco 
En 1917, el belga inicia su colaboración asidua en el diario suizo La Feuille, Bulletin quotidien de la Nation. Incorpora una viñeta diaria centrada en la actualidad, lo que le obliga a apurar al máximo los recursos formales. Los imponderables de esta creación cotidiana le fuerzan a comprimir el guión lo más posible y, dado que sólo dispone de unas horas para concebir la ilustración, compendia la resolución de la imagen al máximo. Con la ayuda del pincel, Masereel efectúa un trazo muy robusto que avala su soltura y rapidez de ejecución. Estos aguazos monócromos intensifican el valor de los negros densos del entintado con el fin de incrementar de este modo la emotividad de la viñeta. En el plano formal ya se anticipan aquí los contrastes violentos que, más adelante, caracterizan sus xilografías.

\subsection{Ilustraciones literarias}

Dentro de su variadísima producción, sobresale su aportación gráfica en las obras literarias de relevantes escritores, amigos personales del artista en muchas ocasiones. La edición ocupa buena parte de su proceso creativo, teniendo en cuenta además que esta tarea proporcionaba a Masereel un contacto directo con la narración poética y literaria de la que extraía los valores iconográficos más sobresalientes ${ }^{32}$. Aportaciones de esta naturaleza apelan siempre a la estrecha colaboración de los autores de los textos y de la imagen. En el caso de los escritores fenecidos, debe proyectar su criterio personal con cautela. El diminuto formato de las matrices a excavar añade otro escollo a este quehacer tan sutil. La calidad de las ilustraciones literarias no empaña la de sus estampas más célebres y, de hecho, su talento en el campo de la ilustración puso en jaque su propia carrera artística. En 1919, Masereel funda, junto con su amigo René Arcos, la editorial Le Sablier, cuyo Ex libris reproduce un reloj de arena en alusión precisamente al paso del tiempo. Esta iniciativa asegura su independencia, pues tantas solicitudes lo sitúan en una directriz mercantilista que lo distancia de su vocación artística.

Su primer trabajo de ilustración literaria xilográfica se inicia en Ginebra, un 25 de mayo de 1917. En aquella ocasión, no se trata ciertamente de un encargo, sino más bien de una elección personal. Excava 57 tacos xilográficos para el citado poemario de Émile Verhaeren, Quinze Poèmes. El resultado final de este esfuerzo determina su evolución técnica en el

32 Animados por editores como Ambroise Vollard y Léon Pichon, algunos artistas conciben el libro como un soporte artístico, cualidad igualmente atribuible a la producción de novelas gráficas de Masereel. BERSIER, J. E.: Op. cit., pp. 344-346. campo del grabado en relieve y afianza la evolución de su estilo personal. El predominio de las áreas negras no mitiga el protagonismo de los blancos más puros. Inserta líneas, punteados y retículas para suavizar la confrontación cromática y equilibrarla visualmente.

Durante toda su vida, concibe muchas ilustraciones para las obras de Romain Rolland, Georges Duhamel, Walt Whitman, Hemingway, Shakespeare, Émile Zola o García Lorca. También consagra matrices al dramaturgo belga Maurice Maeterlinck para el que elabora, en 1921, las imágenes de Le trésor des humbles. Un detenido análisis de tan importantes aportaciones rebasaría la extensión de este artículo, por lo que es preferible remitirse al estudio de Pierre Vorms ${ }^{33}$. Sin embargo, no cabe concluir este epígrafe sin mentar su magistral aportación en el texto Jean-Christophe de Romain Rolland y en la Leyenda de Tijl Uilenspiegel de Charles de Coster.

En este caso talla 160 matrices para Tijl Uilenspiegel (1867), tratándose de otro trabajo primordial, concluido en 1925. La rebelión flamenca contra el dominio español en el siglo XVI, determina el argumento de este cuento nórdico. La obra literaria plantea códigos universales, entre los cuales las luchas de poder y la vulneración de la libertad ultrajada por los Tercios de Flandes. Una vez más, las imágenes desvelan la dialéctica literaria salpicada de tensiones y sufrimientos fruto del conflicto bélico.

El planteamiento compositivo es abiertamente contrastado, pero la repartición de superficies negras y blancas también tiende a equilibrarse. En la mayor parte de las estampas, predomina incluso cierta intensidad de los blancos para destacar, de ese modo, la calidad del dibujo. Algunos tacos, preludian la inflexión estética de 1928, cuando el valor de los aterciopelados se adueña del espacio plástico. Además, el trazo suaviza su contorno lineal, evitando los quiebros y las angulaciones en aras de una gestualidad fluyente y ondulante. El dominio procedimental es evidente, lo que le permite emplear la gubia con la misma destreza que el lápiz y el pincel ${ }^{34}$.

33 Se puede consultar el catálogo general de la obra ilustrada de Masereel en el Fondo Mercator de la ciudad de Amberes. Pierre Vorms y Hanns-Conon von der Gabelentz publican un extracto del mismo en la obra de AVERMAETE, R.: Op. cit., pp. 245-311.

34 El impacto de estas ilustraciones suscita elogios y numerosas exposiciones. El asunto es incluso objeto de un Congreso Internacional en Amberes, "Frans Masereel herdacht in Stade, Tijdens Internationaal Uilenspiegelcongres". Diario Gazet Van Antwerpen, 5 de octubre de 1989. 
Además, inicia igualmente las 700 matrices para la extensísima novela de su amigo Rolland en 1925. El protagonismo de la imagen sobre el discurso plantea varios problemas que empañan la ejecución de las planchas, cuya labor se demora hasta 1927. El trabajo puso a prueba sus mutuas sensibilidades y percepciones artísticas, obligando a los dos autores a coordinar sus creaciones mutuas. El esfuerzo se ve recompensado por la crítica que califica los cinco tomos de Jean-Christophe de "biblia contemporánea". Las imágenes talladas por Masereel no se subordinan al plano literario, pero su destreza formal impactante, tampoco merma el protagonismo del relato en el que se integran a la perfección. En definitiva, las ilustraciones de Masereel no son obras menores y, muy al contrario, igualan la calidad de sus mejores estampas.

\subsection{Novelas gráficas}

En su prolija aportación, la novela gráfica supone acaso una de las cimas más personales y celebradas del xilógrafo, dado que puede expresarse al mismo tiempo como artista plástico y como guionista de sus libros. El planteamiento de esta suerte de literatura en imágenes trasciende incluso el propósito de sus estampas de mayor aliento formal. Masereel construye relatos complejos por medio de la secuenciación de imágenes, utilizando para ello la expresividad de los recursos icónicos. La articulación de sus semblanzas requiere una simbiosis de géneros muy compleja, por cuanto el relato sólo se nutre de la imagen referencial como único vehículo de la narración. De hecho, esta literatura iconográfica omite totalmente el mensaje lingüístico, en tanto que código específico fundamental de la narrativa. La elusión del texto obliga a una síntesis formal en grado extremo para facilitar la divulgación del mensaje.

En el plano de la representación, Masereel repudia la intelectualización de la estética vanguardista. Tal y como se advierte en su correspondencia estaba, ciertamente, al tanto de todas las corrientes experimentales. Omite la abstracción formal en favor de un planteamiento plástico figurativo para concentrar así lo más posible la expresión narrativa e insistir en el plano literario e ideológico. Consciente de la sociedad en la que vive, Frans Masereel se compromete con el internacionalismo pacifista preconizado por Tolstoï y por Walt Whitmann. Desde esta posición política, consagra sus novelas gráficas o biblias para los pobres al proletariado ${ }^{35}$. La estructura de los relatos siempre es fácil de seguir por los lectores. En el plano estilístico, estas creaciones se adscriben al expresionismo con resabios cubistas y futuristas.
A través de su obra, Masereel demuestra siempre su gran conocimiento de la tradición mpresora de Flandes y de los Países Bajos. En sus relatos, actualiza el método de las impresiones tabularias de libros, biblias misales y breviarios. Una vez más, la Primera Guerra Mundial determina la orientación temática de estas creaciones en las que subraya su aversión por el conflicto. Debout les morts - Résurrection infernale y Les morts parlent creaciones realizadas ambas en 1917, abren una senda fascinante en el plano artístico, siendo también obras conmovedoras. A ellas, se añaden otras aportaciones: 25 Images de la passion d'un homme, 1918; Mon livre d'heures, 1919; Le soleil, 1919; Histoire sans paroles, 1920; L'idée, 1920; Souvenirs de mon pays, 1921; La cité, 1925; Mon Pays, 1956, y Antwerpen, 1968.

Este género, anacrónico y tan inusual entonces, le permite codificar, mediante las imágenes, todos sus pensamientos en primera persona, para reflejar las vivencias del protagonista principal, alter ego del propio Masereel. El celebérrimo álbum L'Idée condensa referencias autobiográficas. La desazón de sus primeras novelas se trasmuta en serena cadencia y, algunas aportaciones posteriores, La nuit et ses filles (1959), profieren un tono alegre y sensual. Con el tiempo, su obra se despoja de la rabiosa mordacidad inicial en virtud de un planteamiento afable. Los temas acuáticos, florales y marinos, siempre tan de su gusto, confirman una actitud esperanzada, fruto probablemente de los cambios sociales y políticos acontecidos tras la segunda posguerra.

La ironía gobierna algunas narraciones, como sucede en Mon Livre d'heures, 1919, prologado por Thomas Mann ${ }^{36}$. Fue creado como un remedo de los miniados renacentistas, siguiendo la tradición del libro-objeto bellamente ornamentado (Fig.3). Sólo la nobleza podía procurarse una obra tan maravillosa como Très riches heures de Jean de Berry y Livres u Cuer d'Amours esprits. El xilógrafo emula estas creaciones lujosas, pero las consagra ahora a los menos pudientes. Frente al preciosismo de las ilustraciones miniadas, inserta xilografías muy humildes desprovistas de color, para divulgar su mensaje entre las clases más desfavorecidas ${ }^{37}$. Una vez superada la concepción dibujística de los primeros libros, afianza su estilo sobre el dominio del tallado de las matrices. Los contornos del trazo son angulosos, logrando de este modo fortísimos contrastes bicromáticos que producen efectos tridimensionales.

35 En numerosas ocasiones, el artista manifiesta sus postulados éticos y estéticos. La correspondencia, las entrevistas sonoras $y$ la propia obra junto con la hemerográn son las fuentes más accesibles para la De Republiek der Letteren. Vrij Nederland, 10 de junio de 1995.

36 HERMOSO, B.: "La fascinación de Thomas Mann, por la obra de Frans Masereel". Diario El País. Papeles perdidos, 6 de febrero de 2013 


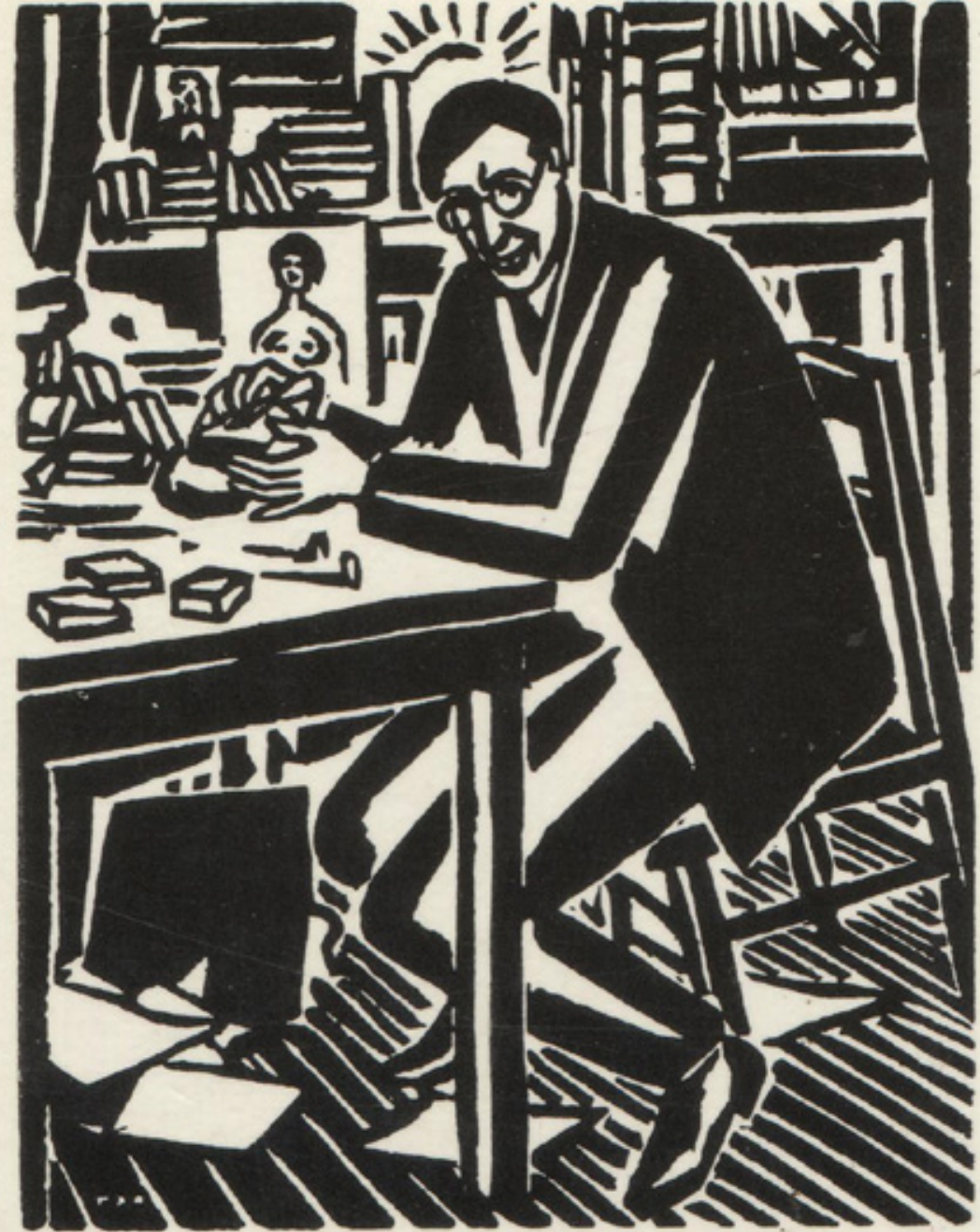

Mon livre d'heures, c.1919 en Catálogo de la exposición Frans Masereel, mayo-junio de 2000, Centro Cultural Cajastur Palacio Revillagigedo, Gijón, detalle de la página 179. Francisco Velasco
Antes de abandonar Ginebra, la editorial Le Sablier, fundada allí junto a su amigo René Arcos, publica en 1921 un álbum anclado en sus vivencias personales: Souvenirs de mon pays. Las dieciséis xilografías que componen este cuento evocan la nostalgia de su tierra natal y pautan diversas historias centradas en una idílica llanura bañada por un sol benefactor. El escenario en el que se desencadenan los acontecimientos narrativos conforma la panorámica descriptiva de un paisaje flamenco. Los lugareños, influidos por patrones de comportamiento universales, como la codicia y la maldad, protagonizan el relato. En este sentido, el artista se vale de arquetipos individuales y colectivos (El furtivo, La campesina, El pescador o Los gendarmes). Esta galería de personajes conforma diversas historias independientes gobernadas por las tradiciones y también por las costumbres populares de Flandes (La procesión, El bar, etc.). El xilógrafo piensa con cautela el argumento literario de sus novelas gráficas sin descuidar tampoco el planteamiento formal ni procedimental. De este modo, logra el máximo equilibrio entre lo dicho y la forma de decirlo.

La connotación simbólica del disco solar, y la electricidad inclusive, son paradigmas afines a las primeras vanguardias que, con frecuencia, también aparecen en las obras del flamenco. El astro como emblema ilustra diversas estampas, entre las cuales L'Armée Nouvelle, 1954. Una sonriente muchedumbre juvenil blande girasoles, a modo de fusiles. En esta iconografía, la vida e inteligencia destellan en partículas de luz frente a la atrocidad de la guerra. Previamente, en 1919, el grabador se presenta al lector, en el frontispicio de su libro Le Soleil, gubia en mano frente a la ventana e iluminado por los rayos solares. En idéntico plano simbólico, crea el álbum La poursuite de la Lumière, cuyo mensaje se refiere a la clarividencia artística.

Mucho más adelante, cuando Masereel se reconcilia con su país natal, al que puede regresar tras su destierro, retoma los asuntos relacionados con la nación belga ${ }^{38}$. La emblemática novela gráfica Mon Pays es un buen ejemplo de ello. En 1956, el autor graba y controla la edición de sus cien matrices, cuya tirada rubrica personalmente un alegórico 25 de diciembre. También cede a la Biblioteca Real de Bélgica los tacos utilizados para la estampación de este álbum. Transidas de emoción, cada una de las matrices del extenso relato evocan un emotivo homenaje a su tierra.

En MASEREEL, F.: "Mijn Getijdenboek". Kunst \& Cultuur, n. ${ }^{\circ}$ 6, 1993, p. 55. 38 En 1946, ilustra el libro de Louis Piérard Regards sur la Belgique. 
El conjunto glosa detenidamente los paisajes urbanos y rurales de Flandes. Los contrastes abruptos, a modo de «tablero de ajedrez», potencian el expresionismo de las imágenes, de una fuerza sobrecogedora ${ }^{39}$. El xilógrafo entreteje alegorías de la vida cotidiana intensificadas por el poder simbólico de las ruinas, las cruces y las tumbas. La firmeza de su compromiso político justifica el desgarro de ciertos grabados, en los que refleja las consecuencias devastadoras de una sociedad desquiciada que, durante las dos guerras mundiales, transformó sus bellas plazas públicas en cementerios, con el fin de improvisar alli las sepulturas de los desgraciados muchachos arrollados por las ominosas confrontaciones.

En 1968, a iniciativa del Banco de París y de los Países Bajos, Fonds Mercator le encarga 78 tacos para la edición del álbum Antwerpen. Incluye igualmente una xilografía original del artista y un prólogo del humanista Roger Avermaete ${ }^{40}$. Tampoco elude la exégesis de otras ciudades como Gante ${ }^{41}$, donde transcurre su infancia y su adolescencia. En 1962, le rinde tributo en Gents Grootheid leidt haar Toekomst (La grandeza de Gante determina su futuro $^{42}$ ). También la iglesia Sainte-Gudule (1961) de Bruselas fue glosada con el mismo propósito laudatorio.

En este contexto, sobresale asimismo una secuencia continua de 18 metros de longitud. A modo de rollo o makimono's ${ }^{43}$, Masereel concibe y ejecuta este relato durante su estancia en la ciudad de Winterthur, en 1942, cuando no dispone de medios ni de utillaje para la

39 Véase TURKY, R: “Antwerpen toont geëngageerde kunst van Frans Masereel”. Diario Gazet van Antwerpen, 4 de octubre de 1989.

40 Roger Avermaete (Amberes, 1893-1988) escritor y crítico de arte. Autor de relevantísimos estudios artísticos, entre los cuales: Rubens (1933), Sinthèse des arts (1963), Rembrandt et son temps (1952), L’Aventure de "Iumière" (1969), Permeke (1970) y Masereel (1975). Promovió personalmente la revista

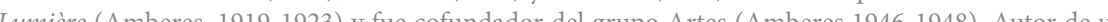

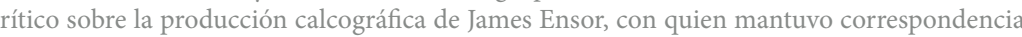
Véase ENSOR, J.: Lettres. Bélgica, Édition Labor, 1998/1999, pp. 33-36.

41 El sector textil arraiga en la ciudad de Gante, frente a la pujanza comercial de Amberes amparada por e puerto. Las hilaturas suponen la única fuente de trabajo para la numerosa mano de obra hacinada en lo extrarradios de Gante. Las condiciones de vida de esta población son semejantes a las de cualquier otro suburbio industrial decimonónico. Masereel descubre allí la pobreza y comprueba el injusto reparto de la riqueza. El artista inicia en Gante su aprendizaje musical y artístico, por lo que el título de la obra sintetiza el peso de las tradiciones culturales la importancia de su industria $y$ tambín la fuerz de una sintetza elpeso de lo masa co 1962. A este respecto también se recomienda el artículo de MONSIEUR, P.: "Met guts en perhout" Kunst \& Cultuur, n. ${ }^{\circ} 10,1995$, pp. 7-8

42 Traducción de la autora. preparación de las matrices ${ }^{44}$. En esta obra, cuenta su éxodo hacia Aviñón y sus amargas vivencias, entre las cuales los bombardeos aterradores, la huida desesperada de la población en medio de la carretera, el cansancio y la muerte acechando siempre en las calzadas. El artista y su mujer, al igual que millares de exiliados, cruzan toda Francia a pie, huyendo del asedio alemán. A partir de este trabajo único, se editan algunos ejemplares expuestos en $1995^{45}$. Al margen de la espectacularidad de sus dimensiones, la voluntad narrativa de su aportación es primordial y confirma el deseo evocador del artista. Una vez más, se vale de la secuenciación gráfica para denunciar las desgarradoras consecuencias de la guerra. Los encuadres singulares, la utilización de líneas cinéticas y la alternancia de planos subjetivos, picados y contrapicados aceleran el ritmo de lectura de todas las escenas. La sensación de movimiento invade esta composición cinematográfica eficaz y sugerente, elaborada tan solo por medio del dibujo acuarelado.

\subsection{Estampas xilografiadas}

Al margen de algunas litografías y unas pocas calcografías, el grabado en relieve sobre madera a la testa engrosa la mayor parte de la carrera artística de Masereel. Las estampas de mayor aliento incrementan sus dimensiones, en comparación con los demás géneros cultivados por el autor. Aún así, en el contexto creativo de las primeras vanguardias, en las que se inserta Masereel, proliferan los pequeños y medianos tamaños. Llegados a este punto de la reflexión, se ha de insistir en las limitaciones de formato del arte gráfico debido a la dificultad de obtener tacos grandes para efectuar la talla, tratándose de un inconveniente importante y complejo de sortear con la madera. En cambio, el linóleo ofrece siempre muchas más posibilidades de trabajo y, de ahí, mayor libertad creativa. En términos de formato y de calidad de la resolución final, el xilógrafo declara su preferencia por las matrices de peral. Otro contratiempo deriva del grosor de los tacos ajustados, en el caso del flamenco, a 23 milímetros (Fig. 4). A partir de la observación de las numerosas matrices conservadas se deduce que este espesor le facilita la estampación tanto en tórculos como en prensas verticales ${ }^{46}$. También le permite tallar ambos lados, si bien la edición de estas dobles matrices precisa de mucha cautela.

43 Rollo de papel o de seda estructurado en horizontal, frente a la disposición vertical del kakemono. 44 DÍAZ GONZÁLEZ, M. M.: Op. cit.,p. 53 .

45 "Masereel. Kanack Weekend". Diario De Morgen, 3 de septiembre de 1995 y "Het rolboek Oorlog overvalt de mensen van Frans Masereel als vredestek”. Diario De Morgen, 3 de septiembre de 1995. 46 Según Patrick Monsieur, el xilógrafo se decantó por el trabajo con gubia y por la madera de peral. 

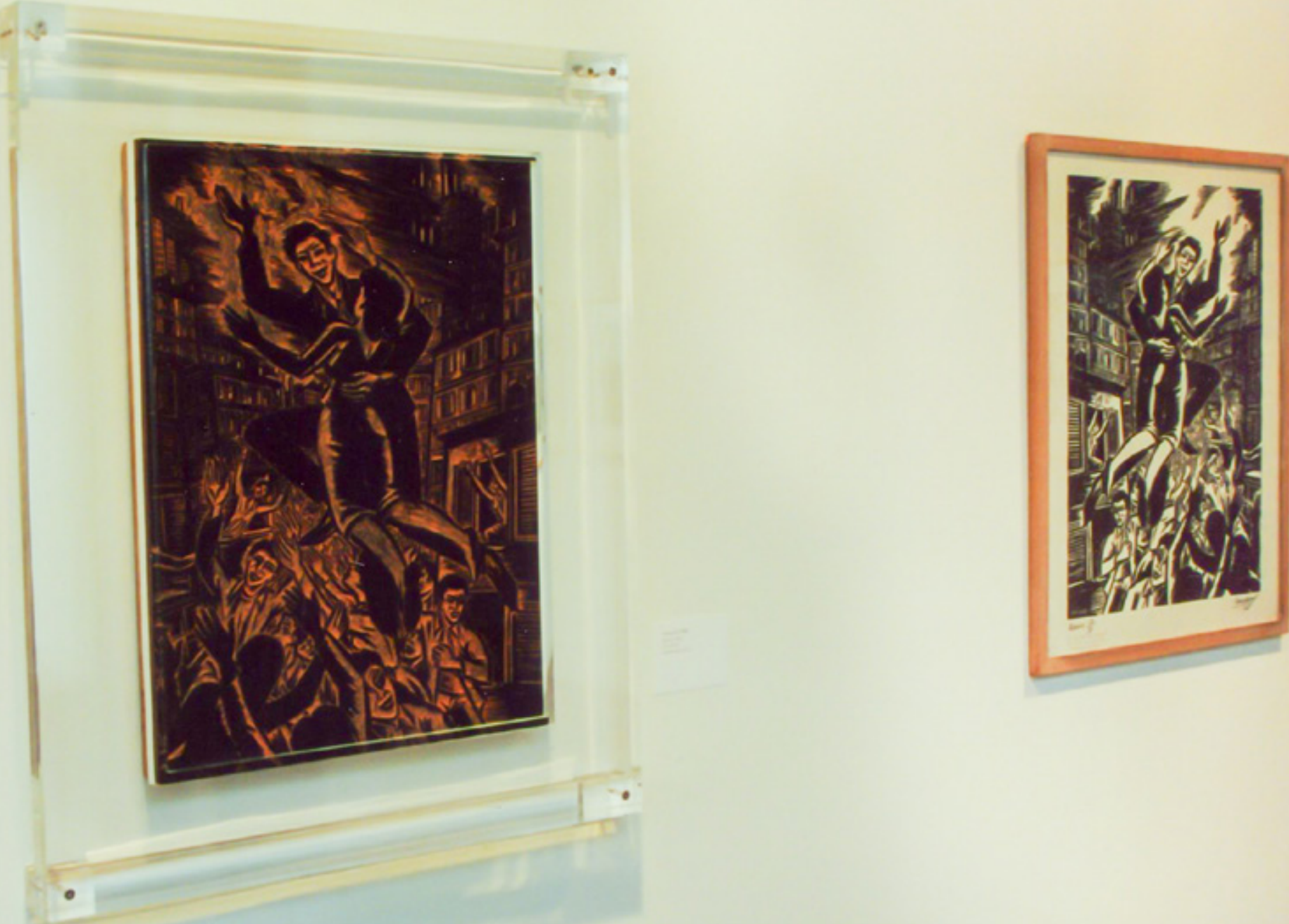

Fig. 4: Ascension, 1968. Matriz xilográfica. Madera de peral de 23 milímetros de espesor. Estampa Ascension, 1968. Centro Cultural Cajastur Palacio Revillagigedo, Gijón. Francisco Velasco 
La versatilidad creativa demostrada por el autor en los diversos géneros no ha restado unidad temática ni estética a toda su producción. Su compromiso social y su narrativa dominan el espacio plástico, afianzado sobre los asuntos tratados y el plano formal. Al igual que en las imágenes de los álbumes, sus estampas propenden a una distribución rectangula del soporte, y en disposición vertical preferentemente, lo que procura un certero equilibrio a la composición general. Los contrastes de las tintas negras sobre el soporte del papel y la potencia del trazo dibujístico anguloso, por efecto de la talla, animan la monotonía de esta disposición clásica de la huella, encuadrada por el amplio marco del birlí. A través de algunas instantáneas podemos observar al artista en su estudio, excavando con gubias y punzones sus matrices ${ }^{47}$. Concluida la fase preparatoria de los tacos, también controla las tiradas de las pruebas de estado y las ediciones finales, efectuadas en los talleres de estampación.

Dentro de los asuntos tratados por Masereel, el hombre en tanto que ser social es un tema recurrente en su imaginario personal. En efecto, el planteamiento humanista anega todas sus creaciones, prestando especial cuidado al género del retrato y autorretrato. Inmortaliza la efigie de su primera esposa Pauline Imhof en 1923 y, en 1968, la de su aún novia Laure Malclès, con la que contrae segundas nupcias un año después ${ }^{48}$. Ya se insiste líneas arriba en su deseo de representar a sus amigos, como el pintor Le Fauconnier, 1922. En su figura de perfil, destaca una mirada hipnótica de halcón alusiva a su fisonomía de ave rapaz que justifica su apelativo coloquial. La personalidad melancólica de su admirado Emile Verhaeren (1920) se erige simbólicamente sobre la ciudad ${ }^{49}$, pero Masereel también remarca su rictus lacónico y triste $\mathrm{e}^{50}$. Bien sea por medio del dibujo o del grabado, sus efigiados denotan siempre una estimable introspección psicológica.

47 ROUSSEEUW, B.: "Humanist en vijftiger". Diario Gazet Van Antwerpen, 17 de junio de 1995.

$48 \mathrm{El}$ autor emplea el óleo para el retrato de Pauline Imhoff, mientras elige la tinta en suaves gradaciones tonales con una prestancia abocetada, en el de Laure Malclès. VAN PARIJS, J.: Op. cit., p. 39 y AVERMAETE, R.: Op. cit. Epígrafe La Fin, pp. 83-85,

49 IGNACIO VELÁZQUEZ, J.: "La escritura tentacular y la ciudad conflictual en Verhaeren". Correspondance,.$^{\circ} 3$, octubre de 1993, pp. 63-70.

50 Dentro del mismo tema cultivado por el poeta destaco igualmente el interesantísimo artículo de SOROS, J.: La ciudad tentacular en dos poemas de Émile Verhaeren y una ilustración de Frans Masereel. Ángulo Recto. Revista de estudios sobre la ciudad como espacio plural, vol. 3, n. ${ }^{\circ}$ 2, 2011, pp. 279-291. http://revistas.ucm.es/index.php/ANRE/article/view/38032/36786. [Consultado el 25/06/2018].
El autorretrato es otra línea de trabajo muy querida del artista, que concede mucha importancia a la expresión de su propia agudeza visual. El interés por este género se remonta a sus años de formación, cuando intercambiaba con Jules de Bruycker afinidades estéticas. En 1972, la Régie des Postes Belges estampilló tras su fallecimiento un sello con una de sus más célebres autorrepresentaciones de perfil. Realizada en 1923, Masereel resuelve su propia imagen con una gran economía de medios y a partir de la extracción del material sobrante. Logra de este modo la masa blanca de su efigie, concretada tan sólo con algunos rasgos característicos. Observador escéptico y desencantado, al igual que los protagonistas de sus novelas gráficas, su mirada destella detrás de las gafas.

El artista se conoce bien, y se interpreta sin ambages, evitando la más mínima complacencia. La galería de autorretratos faculta al espectador para detener su análisis en los cambios anímicos y fisonómicos del xilógrafo a lo largo de su vida. Desde estas representaciones, podemos valorar sin duda alguna las inflexiones de su impetuoso carácter juvenil, suavizado y sereno en su madurez.

Una vez concluida la Gran Guerra, Masereel centra sus puntos de vista sobre las lacras causadas por el capitalismo voraz y despiadado. Sus creaciones denuncian la opresión del poder económico sobre las clases más desfavorecidas. Los mensajes siempre son muy concisos y clarividentes, pero sus estampas también procuran posibilidades de interpretación tal y como sucede en Le gourmand, 1923. La imagen de un glotón prominente no mitiga el mundo de los desheredados, los hambrientos y los famélicos, que se delinean subrepticiamente en la mente del espectador desde la contemplación de esta escena hiriente.

Buena parte de su producción transmite un sentimiento del mundo agrio y desesperanzado. La avaricia se presenta como una metonimia del credo capitalista, capaz de convertir en humo los valores sociales. Muchas de sus estampas y también las imágenes de sus libros se refieren a las lacras de la industrialización siderometalúrgica belga, aparejada a la explotación de hombres, mujeres y niños, deterioros del paisaje y contaminación acústica y ambiental. No son pocas las alusiones del artista en este sentido, teniendo además en cuenta que Valonia, tras Inglaterra, asume muy pronto la Primera Revolución Industrial. En 1920, el xilógrafo crea Les Fumées, donde las chimeneas fabriles volatilizan hombres y mujeres, convertidos en ceniza, anticipando premonitoriamente los hornos crematorios de Auschwitz ${ }^{51}$.

51 DÍAZ GONZÁLEZ, M. M.: Op. cit., pp. 55-60. 
Por lo contrario, el amor es un bálsamo maravilloso en medio de esta escalada bélica, tratándose de la única emoción que engrandece verdaderamente al ser humano ${ }^{52}$. Le baiser, 1924, muestra el júbilo y la alegría de una pareja feliz, abrazándose por encima de la vorágine de la ciudad. De más tardía realización, Le poète amoureux, 1955, también aborda la ilusión y dicha del beso (Fig.5). En esta ocasión, el protagonista estira su cuerpo hasta la buhardilla de su amada. El sentimiento amoroso traspasa las leyes científicas, disuelve las barreras físicas y convierte a los protagonistas en seres prodigiosos, capaces de superar todas las limitaciones. El xilógrafo traza de nuevo un escenario urbano nocturno, iluminado por dos farolas y el resplandor de las ventanas, recreando así una atmósfera de la ciudad muy expresiva ${ }^{53}$. Las metrópolis bañadas por mortecinos destellos, las simbólicas industriales y el ajetreo de la vida moderna responden a las codificaciones de las primeras vanguardias. Skycrapers, 1926, pone una vez más el énfasis en los rascacielos de las grandes ciudades, habitadas igualmente por artistas ${ }^{54}$

En el otro extremo de la panoplia de asuntos maserelianos, se sitúa el desamor perceptible en la pareja que compone la estampa Spleen, 1924. La gran urbe devora al individuo transido de angustia vital, marchitado y abandonado a su suerte ${ }^{55}$. Como delata Poubelles, 1967, la decrepitud y la desidia de la vida moderna nos arroja a la calzada, junto a la basura y las inmundicias. En las tragedias clásicas los actores esconden sus rostros tras el antifaz para ocultar sus verdaderos sentimientos. Así lo refleja Masques, 1948, donde una parej desencadena su burlesca representación. En el plano formal, la depuradísima factura de la

52 A este respecto el artista ha comentado: "L'amour me semble le principal moteur d'une vie, digne dềtre vécue. Aimer autrui nest qu'un début, il faut aimer le plus possible et de telle façon quoon puisse haï fortement ce qui nest pas digne de lêtre" en AVERMAETE, R.: Op. cit. «Epigraphe: Nouveaux Albums», pp. 69-71.

53 En el imaginario masereliano la temática urbana es muy prolija en toda su obra incluyendo sus acuarelas y óleos. A este respecto es interesante destacar el siguiente trabajo fin de carrera DE DONCKER L.: De weergave van de grootstad in het werk van Frans Masereel, Facultad de Artes y Filosofía, Departamento de Arte, Música y Ciencias del Teatro, Universidad de Gante, Universidad de Gante, 2012-2013. Su autora, Lize De Doncker se detiene en el análisis global de las representaciones de las metrópolis, incluyendo comentarios relativos a las fábricas, iglesias, catedrales, calles, tiendas y plazas públicas, que aparecen en las creaciones del artista flamenco.

54 ZABALBESCOA, A.: "Leer la ciudad". Diario El País. Del tirador a la ciudad, 23 de marzo de 2012. https://elpais.com/elpais/2012/03/23/del_tirador_a_la_ciudad/1332484800_133248.html. [Consultado el $18 / 06 / 2020]$

55 Véase CARRERAS DURO, M.: "La ciudad de Frans Masereel". Ángulo Recto. Revista de estudios sobre ha ciudad como espacio plural, vol. 4, n. ${ }^{\circ}$ 2, 2012, pp. 193-195. http://webs.ucm.es/info/angulo/volumen/ Volumen04-2/resenas02.htm. [Consultado el 10/08/2013].

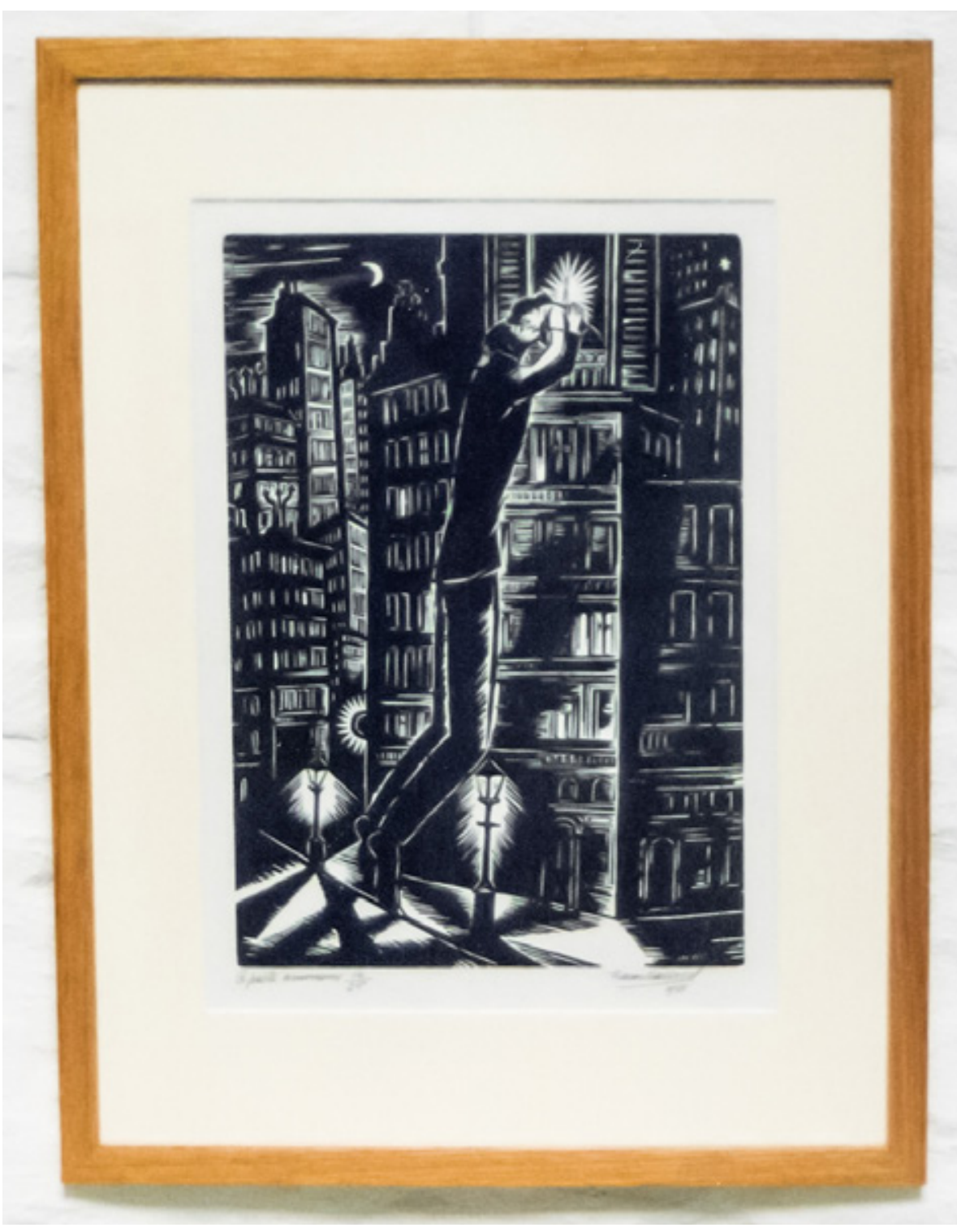

Fig. 5: Le poète amoureux, 1955. Frans Masereel Centrum, Kasterlee, Bélgica, 1997. Francisco Velasco 
obra L’Accusée, 1925, incrementa su valor narrativo (Fig. 6). Esta creación determina una inflexión estilística en su evolución, dado que a partir de este momento concede mayor protagonismo a los tonos negros, de una intensidad sobrecogedora, frente a los destellos del blanco más puro ${ }^{56}$

Dentro de su universo simbólico, el concepto religioso halla cierto acomodo en su trayectoria artística y en su pensamiento. Muy a menudo, el tratamiento es crítico como sucede en La vierge folle, 1923, pero el autor establece a veces un paralelismo entre lo religioso y lo profano. En De calvarie, 1923, el hombre padece el mismo suplicio que Cristo, siendo sometido a idénticos tormentos ${ }^{57}$.

En clave personal, la música desempeña un papel relevantísimo en su vida privada, ya que su padre era violonchelista. Inicialmente, el grabador alberga dudas acerca de la vertiente artística a seguir, por lo que nunca dejó de tocar el acordeón como corroboran muchas fotografías ${ }^{58}$. Dentro de su extenso repertorio, es habitual encontrar esta temática que atestigua su entusiasmo melómano, del cual es buen ejemplo La chanteuse, 1923. En efecto, también se declara gran aficionado al jazz interpretado en reductos marginales y en burdeles, donde las bailarinas se contoneaban al ritmo frenético de los acordes, tal y como lo expresa la estampa xilografiada de 1931 (Fig. 7).

El pálpito emocional que habita en las creaciones de Masereel apela a nuestra conciencia Si se concentra en la denuncia descarnada, también la sensualidad, la ternura y la alegría se abren paso en algunas obras: Désir, 1921; Les Amoureux, 1922; Le Baiser, 1924; La Sirène, 1928; La Nuit, 1936; Hommage à Baudelaire, 1946; Le Poète Amoureux, 1955 y Conte de Fées, 1959. La concisión de determinadas composiciones no aminora nunca su sentido crítico encauzado por medio de la sátira, el sarcasmo y la causticidad de sus prolijos argumentos.

56 LEÓN, V.: "«No hay mejor color que el negro» de Frans Masereel”. Diario El País, 5 de marzo de 2014 57 En las entrevistas que mantuvo con el cineasta Frans Buyens, Masereel se declaró agnóstico. Afirmó su creencia en el hombre y en la humanidad, aunque la figura de Cristo le interesó especialmente: "Je pense que tout individu qui possède une sensibilité humaine, artistique, politique ou sociale, doit être frappé par la figure légendaire du Christ qui sort vivant de la plus belle légende -basée probablement sur quêpar la figure lé ques faits reels-invextirper toutes les vilenies de la société et qui ont payé de leur vie, la lutte qu'ils menaient pour un idéal humain. Le Christ fut l'un d'eux et parmi les plus grands"

58 Durante toda su vida cultivó su arraigada afición musical.
En definitiva, y como ya se insistió más arriba en varias ocasiones, toda la producción gráfica de Masereel responde a la estética vanguardista del primer tercio del siglo XX, entroncando estilísticamente con movimientos de gran modernidad, como el expresionismo y también el Art Déco. Deudor, en este caso, del cubismo sintético en su configuración referencial iconográfica, o de vuelta al orden, más conveniente a Masereel para la traslación de sus múltiples mensajes sociales y políticos. Sus composiciones tan sumarias a nivel estético, y procedimental, destellan siempre plenas de luminosidad, desde el contraste del negro sobre el fondo del soporte blanco o de tono agarbanzado.

\subsection{Acuarelas y óleos}

Masereel domina igualmente otras técnicas artísticas, aunque sobresale sin duda alguna la extraordinaria calidad de su obra múltiple por encima de todas las demás. Se consagra a la acuarela antes que a la pintura que le interesa menos y por compromiso, como él mismo expresa $^{59}$. Para este dibujante y grabador, imbuido por el bicromatismo más estricto de blancos y negros, el aguazo es una técnica de transición hacia el óleo.

La composición de sus obras únicas no renuncia a los cánones del dibujo y, de hecho está sustentada por un potente entramado gráfico sobre el vibrante colorido del fondo. El sentido contestatario de sus estampas y de sus novelas gráficas desaparece en las pinturas al óleo y en las acuarelas, mucho más atemperadas y complacientes. Desprovistas del mordiente crítico que caracteriza su obra gráfica, estas aportaciones más bien responden al código formal expresionista, si bien en un registro sereno y estático frente a las afiladas propuestas de los artistas alemanes de Die Brücke.

En cierto sentido, apela igualmente a las corrientes metafísicas en determinadas escenas, en las que se petrifican el fluir del tiempo y del espacio. Dentro de los asuntos despuntan las vistas urbanas (Sous le métro, 1923); escenas de interior (Bureau II, Patron de face, 1925); secuencias de bares (Chez le bistro, 1925) y diversos rincones parisinos. Tampoco faltan los puertos pesqueros, la figura humana y las siluetas de las grúas.

59 "Je faisais peu de peinture, mais beaucoup de blanc et noir. J'ai toujours eu une prédilection pour le dessin et le tableau de chevalet métait peu sympathique, tout en croyant toutefois qu'il était nécessaire de peindre" en AVERMAETE, R.: Op. cit., p. 43. 


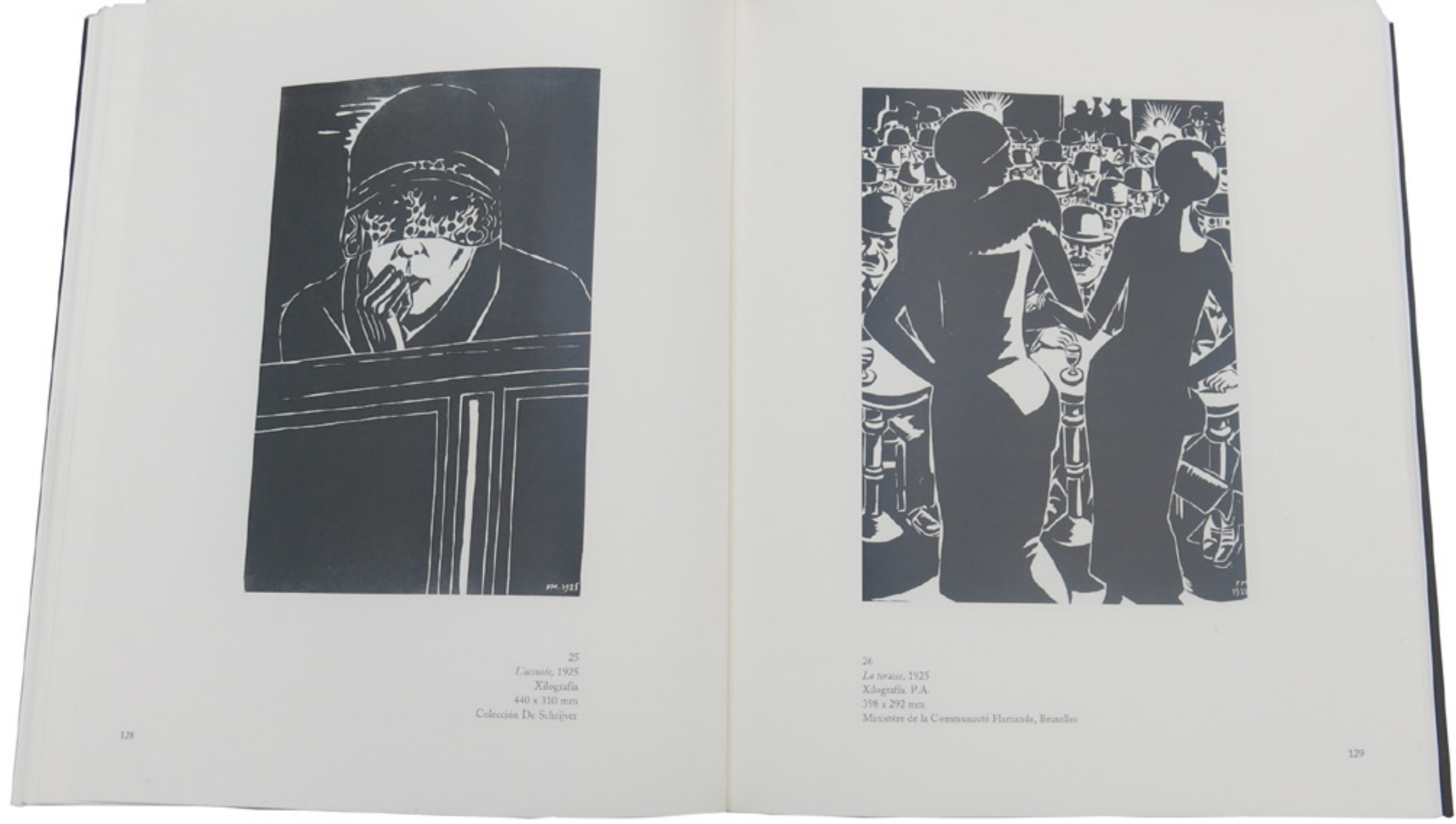

Fig. 6: L’accusée y La terasse, estampas xilografiadas, 1917 en Catálogo de la exposición Frans Masereel, mayo-junio de 2000, Centro Cultural Cajastur Palacio Revillagigedo, Gijón, pp. 104-105. Francisco Velasco 

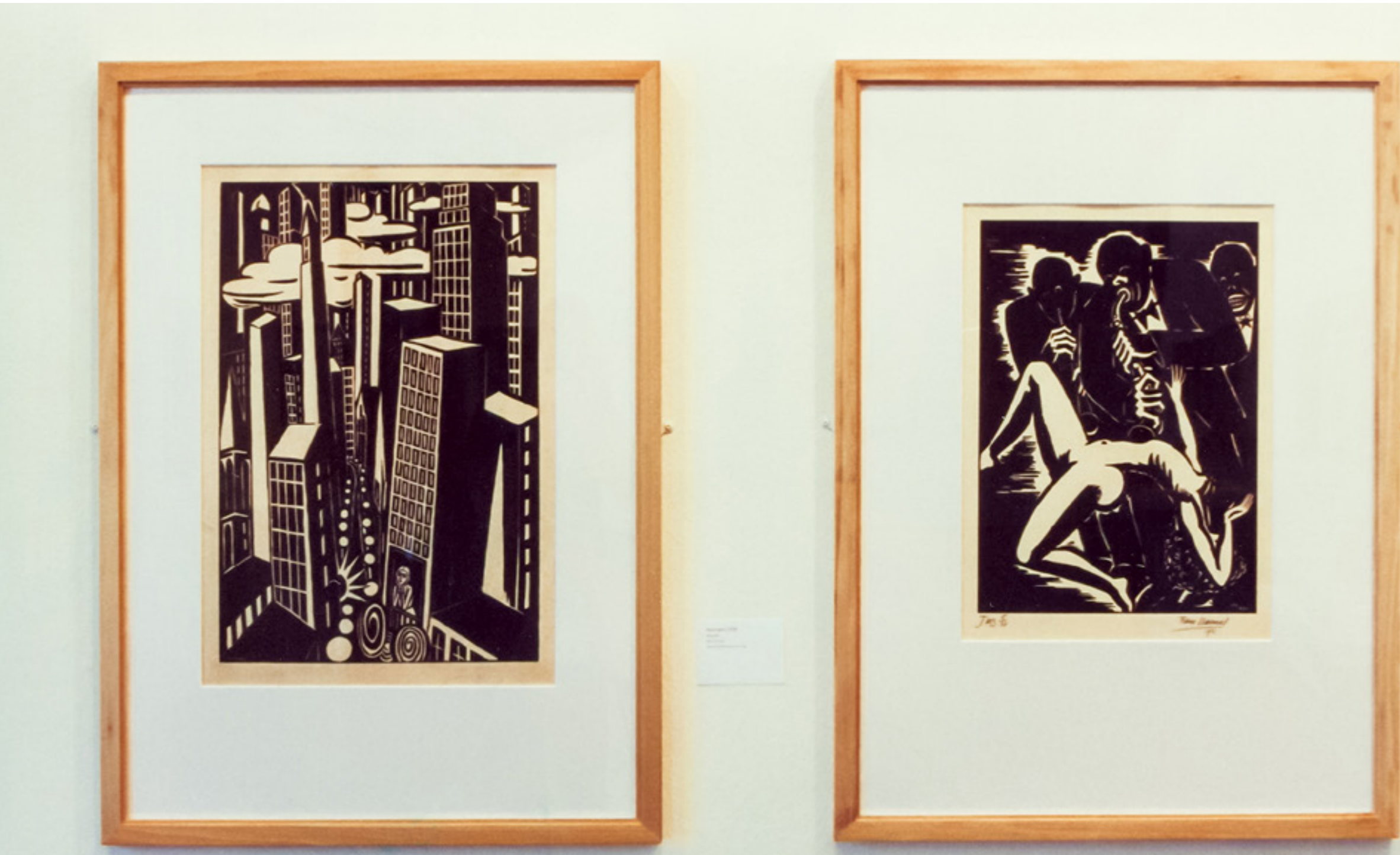

7: . Skycrapers, 1926, y Jazz, 1931. Centro Cultural Cajastur Palacio Revillagigedo, Gijón. Francisco Velasco 
En consonancia con el retorno al orden decretado por Picasso en la década de 1920, la monumentalidad de la figura humana define la producción pictórica de Masereel. Por medio de vigorosos toques de pincel y una cromática tornasolada, resuelve en 1928 el retrato de su madre. El fondo gris plateado y el colorido del vestido ponen en valor la representación de la anciana acomodada en un butacón. En la mayor parte de sus óleos, el artista prescinde del dibujo y vertebra la composición por medio del color, cuya pincelada se escinde empastada en forma de cuña. Ciertamente, en la década de 1940, el trazo potente y gestual también estructura el espacio plástico de algunas obras (Man met pijp, 1948; Songeuse, 1948; Vrouw sluit het venster, 1948).

Su voluntad de síntesis compositiva en el plano pictórico se asienta sobre su admiración por Cézanne, uno de sus artistas predilectos, y en esta deriva cézaniana se citan varias obras: Deux femmes au réverbère, 1927; Port de Boulogne-sur-Mer, 1928; Maison de pêcheurs, Equihem, y Maison sur la falaise, 1929. Del surrealismo entonces en boga asume el efecto de extrañamiento espacial, concretado en un ser humano devorado por la inmensidad sublime del paisaje.

En términos pictóricos, el flamenco se sitúa en la senda de la Escuela de Laethem-SaintMartin, con Permeke (Amberes, 1886-Ostende, 1952) y Van de Berghe (Gante, 1883 1939) a la cabeza. La plástica contemporánea belga despunta en el panorama artístico internacional, rayando igualmente a la mejor altura. Frente a la causticidad de su obra múltiple, consciente en este caso de su eficacia en la divulgación de los mensajes, las pinturas y acuarelas de Masereel transmiten una atmósfera muy apacible y distanciada de la realidad social, que trasciende áspera y pinchosa en sus estampas xilografiadas.

\section{CONCLUSIONES}

A partir de las reflexiones enunciadas líneas arriba, aún se verifica en nuestro país cierta opacidad respecto a esta figura artística de relevancia internacional. Se incrementan ahora ciertamente los artículos en prensa y también los análisis en revistas científicas, pero lamentablemente las magníficas estampas del xilógrafo belga no alcanzan aquí pleno reconocimiento. El condicionante de la obra múltiple como creación de segunda categoría es uno de los factores que mitigan la visibilidad de sus originales aportaciones en España, al igual que sucede con otros grabadores nacionales e internacionales.

Entre las cualidades personales maserelianas más certeras, cabe citar la hondura de su credo sociopolítico que lo impele a la crítica virulenta y a la denuncia. Su sentido de la libertad cala en la versatilidad de los asuntos creativos, transidos de ideología. Milita primero en las filas del pacifismo ginebrino y se involucra, más adelante, en los partidos de izquierda. El calado de su primer compromiso le induce a la deserción de los frentes de batalla durante la Primera Guerra Mundial, aceptando sus graves consecuencias durante casi dos décadas.

Asume el aprendizaje del grabado en relieve de manera personal y autónoma y sus grandes logros formales contribuyeron a situar esta disciplina en la cúspide de la renovación estética vanguardista. En efecto, la crítica internacional prodiga la mejor consideración a su trayectoria destacando su producción xilográfica dentro de las más relevantes del panorama artístico internacional. La ecuación arte y vida es un referente del dogma vanguardista y, asimismo, un planteamiento fundamental de Masereel. Aunque desarrolló trabajos colaborativos con varios literatos para la ilustración de sus textos y poemas, el artista se decantó por el trabajo individual en solitario frente a la agrupación De Vijf, donde quedó integrado a su pesar.

En el plano formal, canaliza la virulencia de su sentimiento crítico por medio de una composición figurativa clara y concisa. La complejidad narrativa de sus relatos en imágenes no mitiga el equilibrio de los recursos iconográficos, siempre al servicio de los mensajes transmitidos. Todas las aportaciones del autor flamenco son legibles, fáciles de entender y de asimilar y, aun así, también ofrecen diversas posibilidades de interpretación. Ninguna de sus estampas, ni tampoco sus novelas gráficas, agota su discurso plástico y conceptual en una sola mirada. Por el contrario, su trabajo incita siempre al lector de sus libros y de sus estampas a emprender revisiones críticas, y constantes relecturas. 
El alcance de su legado traspasa Centroeuropa, penetrando por ejemplo en la antigua Unión Soviética, China y México ${ }^{60}$. La renovación propugnada por el xilógrafo influye directamente en el panorama artístico internacional, e indirectamente, también en España $^{61}$, aunque mucho más adelante. A mediados de 1950, José García Ortega (Arroba de los Montes, Ciudad Real, 1921-París, 1990) también entrevé la estampa, al igual que el belga, como un instrumento de divulgación cultural y de concienciación política.

El arte múltiple permite abaratar la producción y amplificar la difusión de los mensajes, tal y como también sostiene Masereel desde su postulado ético y artístico. Sin la referencia del flamenco y sin las iniciativas propugnadas a este respecto en México, no cabe entender el proyecto artístico español Estampa Popular ${ }^{2}$. Francisco Álvarez, uno de los miembros fundadores de las agrupaciones regionales, surgidas durante la tibia apertura franquista, reconoce la influencia de estas dos corrientes precursoras ${ }^{63}$.

En definitiva, tras el somero repaso de su vida y de su extensa trayectoria vanguardista, el referente estético de Frans Masereel se erige, sin duda alguna, en trascendente. El calado, la diversidad y complejidad de su producción son determinantes en cuanto a la consagración de la obra gráfica como una disciplina artística de primer nivel y en todos sus planos creativos. Su compromiso social también alcanza su expresión formal más lograda, especialmente, en sus estampas y en sus libros de imágenes o biblias de los pobres, donde el mensaje aportado es accesible a todos los públicos.

60 En GAUDIBERT, P.: "Frans Masereel et la diffusión internationnale de la gravure sur bois et sur lino" en AA.VV.: 50 Ans de gravures sur bois chinoises 1930-1980. Grenoble, Maison de la Culture de Grenoble, 1981, p. 3.

61 También se advierte cierta sintonía estética en alguna xilografía de Francisco Bores (Madrid, 1898-París, 1972). SAMANIEGO, F: "Francisco Bores ilustra el ambiente literario madrileño de los años veinte". Diario El País, 18 de septiembre de 1999.

62 Los muralistas Leopoldo Méndez (1902-1969), Luis Arenal (1909-1985) y Pablo O’Higgins fundan, en 1937, el Taller de Gráfica Popular que entronca con el realismo socialista y con la estética de Masereel.

63 Más información en GANDÍA, J.: Estampa Popular. Valencia, IVAM Centre Julio González, 1996 y en MIRALLES, F.; QUERALT, R.: "En torno al grabado catalán de posguerra". Estudios Pro Arte-10, Grabado Español Contemporáneo. Barcelona, Fundación General Mediterránea, 1977, pp. 44-67. 
IA PRODUCCIÓN XILOGŔAFICA DE FRANS MASEREEL (1889-1972) ILUSTRACIONES, ESTAMPAS Y NOVELAS GRÁFICAS AL SERVICIO DEL COMPROMISO SOCIAL

\section{BIBLIOGRAFÍA}

AA.VV.: Frans Masereel Centrum. Obra Gràfica. Baleares, Ministerie van de Vlaamse Gemeenschap y Caixa Balears, 1994.

AVERMAETE, R.: Frans Masereel. Amberes, Fonds Mercador, 1975.

BARÓN THAIDIGSMANN, J.; MORALES MATOS, G.: Arte y Sociedad en Bélgica. 1848 1914. Oviedo, Museo de Bellas Artes de Asturias, 1985.

BERSIER, J. E.: La Gravure. Les proceédés, L’histoire. París, Ed. Berger-Levrault, 1963, pp. 341-344.

BITSCH, M. T.: Histoire de Bélgique. París, Hatier, 1992.

BRACKE, E.: “Jorijs Van Parys over zijn Frans Masereel-biografíe”. Diario De Morgen, 28 de abril de 1995.

BRACKE, E.: "Frans Masereel, een onvergetelijke kunstenaar". Doen-(Stad-Antwerpen), 10 de enero de 1997.

BUYENS, F.: Frans Masereel, Ik hou van zwart \& wit. Films Lyda Dacapo, 42 minutos, 1969.

BUYENS, F.: Frans Masereel, Aspecten van zijn werk. Films Lyda Dacapo, 60 minutos, 1980

CARRERAS DURO, M.: "La ciudad de Frans Masereel". Ángulo Recto. Revista de estudios sobre la ciudad como espacio plural, vol. 4, n. ${ }^{\circ}$ 2, 2012, pp. 193-195. http://webs.ucm.es/ info/angulo/volumen/Volumen04-2/resenas02.htm. [Consultado el 10/08/2013].

DE DECKER, J.: “La traversée du siècle de Masereel”. Diario Le Soir, 15 de enero de 1996.

DE DONCKER, L.: De weergave van de grootstad in het werk van Frans Masereel, Facultad de Artes y Filosofía, Departamento de Arte, Música y Ciencias del Teatro, Universidad de Gante, Universidad de Gante, 2012-2013.

“De Vijf van Lumière”. Trends, 3 de julio de 1997.
DÍAZ GONZÁLEZ, M. M.: Obra gráfica, Frans Masereel Centrum. Oviedo, Caja de Ahorros de Asturias, Obra Social y Cultural, 1996.

DÍAZ GONZÁLEZ, M. M.: Frans Masereel. Oviedo, Cajastur, Obra Social y Cultural, 2000.

Documentales Frans Masereel, rtbf.be. https://www.rtbf.be/culture/arts/detail_frans-masereel-images-de-resistance?id=9651551 [Consultado el 03/02/2020].

DOSOGNE, L.: "Artiesten kerven hun ziel in hout voor "Lumière". Diario Gazet van Antwerpen, 17 de julio de 1997.

ENSOR, J.: Lettres. Édition établie par Xavier Tricot, Bélgica, Archives du Futur, Édition Labor, 1998/1999.

"Frans Masereel herdacht in Stade, Tijdens Internationaal Uilenspiegelcongres". Diario Gazet Van Antwerpen, 5 de octubre de 1989.

Frans Masereel. http://www.jorisvanparys.com/fransmasereel-un.html [Consultado el $13 / 08 / 2016]$.

Frans Masereel Centrum. http://fransmasereelcentrum.be/en/ [Consultado el 13/08/2016]

Fundación Frans Masereel. http://www.frans-masereel.de/ [Consultado el 13/08/2016].

GANDÍA, J.: Estampa Popular. Valencia, Centre Julio González, abril/junio 1996.

GAUDIBERT, P.: "Frans Masereel et la diffusión internationnale de la gravure sur bois et sur lino" en AA.VV.: 50 Ans de gravures sur bois chinoises 1930-1980. Grenoble, Maison de la Culture de Grenoble, 1981.

GONZÁLEZ SALVADOR, A. (dir.): "El simbolismo belga”. Correspondance, n. ${ }^{\circ}$ 3, octubre de 1993.

GYSELEN, G.: "La gravure sur bois et sur linoléum en Flandre à l'époque de la Grande Guerre”. Revue de Culture Néerlandaise. Septentrion, 1/84, 13e Année, 1984, pp. 17-24. 
HERMOSO, B.: "La fascinación de Thomas Mann, por la obra de Frans Masereel”. Diario El País. Papeles perdidos, 6 de febrero de 2013.

HEARD HAMILTON, G.: Pintura y escultura en Europa. 1880/1940. Madrid, Cátedra, 1980.

HOLSBEEK, D.: “Meesters houtsnijkunst”. Diario De Standaard, 24 de julio de 1997.

HOOZEE, R.: Tekeningen, pastels en aquarellen uit eigen collectie. Gante, Catálogo General de Fondos del Museum voor Schone Kunsten, Museo de Bellas Artes de Gante, 1985.

HOOZE, R.; VANFLETEREN, H.: "Frans Masereel” en AA.VV.: Frans Masereel Centrum Obra gràfica. Baleares, Ministerie van de Vlaamse Gemeenchap y Caixa de Balears, 1994.

HOUWEN, H.: "De Betekenis van Frans Masereel als Houtsnijder". De Koerier, Rodenvachfonds, 6 de septiembre de 1993.

IGNACIO VELÁZQUEZ, J.: "La escritura tentacular y la ciudad conflictual en Verhaeren". Correspondance, n. ${ }^{\circ}$ 3, octubre de 1993, pp. 63-70.

LEÓN, V.: “«No hay mejor color que el negro» de Frans Masereel”. Diario El País, 5 de marzo de 2014

MAEREEL, F.: "Masereel Getijdenboek". Kunst \& Cultuur, n. ㅇ 6, 1993

MASEREEL, F.: Du noir au blanc. 1939

MASEREEL, F.: Catálogo. Niza, 1965.

MARTÍNEZ LÓPEZ, B.; La destrucción en el arte. Evolución y síntesis de las manifestaciones de la pintura vanguardista europea a través de los conflictos de la primera mitad del siglo XX. Oviedo, Facultad de Filosofía y Letras, Universidad de Oviedo, julio de 2017.

MATILLA, J. M.: "Imágenes del horror: de la comunicación a la reflexión" en AA.VV. Estampas de la Guerra de la Independencia. Madrid, Museo Municipal de Madrid, Calcografía Nacional, Obra Social y Cultural de Caja de Ahorros de Asturias, 1996, pp.13-16.
MIN, E.: "Het geweld van zwart en wit". Diario De Morgen, 10 de julio de 1997.

MIRALLES, F; QUERALT, R.: “En torno al grabado catalán de posguerra”. Estudios Pro Arte-10, Grabado Español Contemporáneo. Barcelona, Fundación General Mediterránea, 1977, pp. 46-67.

MOERBEEK: “Frans Masereel, Beeld Dichter van het proletariaat". De Republiek der Letteren. Vrij Nederland, 10 de junio de 1995.

MONSIEUR, P.: “Met guts en perhout”. Kunst \& Cultuur, n. ${ }^{\circ}$ 10, 1995.

MORALES, J. L.: Diccionario de Iconología y Simbología. Madrid, Taurus Ediciones, 1984.

NAGELS, M.: Jules de Bruycker etser. Gante, Museum voor Schone Kunsten, 1995.

ROUSSEEUW, B.: "Humanist en vijftiger". Diario Gazet van Antwerpen, 17 de junio de 1995.

SAMANIEGO, F.: "Francisco Bores ilustra el ambiente literario madrileño de los años veinte”. Diario El País, 18 de septiembre de 1999.

SOROS, J.: "La ciudad tentacular en dos poemas de Émile Verhaeren y una ilustración de Frans Masereel". Ángulo Recto. Revista de estudios sobre la ciudad como espacio plural, vol. 3, n. ${ }^{\circ}$ 2, 2011, pp. 279-291. http://revistas.ucm.es/index.php/ANRE/article/ view/38032/36786. [Consultado el 25/06/2018].

TONDEUR, M.: "Des hommes contre, 1914-1918: artistes et écrivains contre la guerre". Revue d'Études marxistes, n. ${ }^{\circ}$ 110, 2015 http://www.marx.be/fr/content/\%C3\%A9tudes-marxistes-no-110 [Consultado el 01/08/2018].

TURKY, R.: “Antwerpen toont geëngageerde kunst van Frans Masereel”. Diario Gazet van Antwerpen, el 4 de octubre 1989.

VAN AUTENBOER, E.: "La industria de los naipes de Turnhout (1826-1976)". Noticias de Bélgica, n. ${ }^{\circ}$ 166. Bruselas, Ministerio de Asuntos extranjeros, 1976, pp. 144-145. 
VAN DEN BOSSCHE, O.: "Frans Masereel (1889-1972): idéalisme dans l'art d’un témoin de l'histoire". Arts \& Sociétés, n. ${ }^{\circ}$ 42, 2012. http://www.sciencespo.fr/artsetsocietes/fr/archives/1694 [Consultado el 04/08/2019].

VANFLETEREN, H.: "Frans Masereel”. Frans Masereel Centrum, Obra gràfica. Baleares: Ministerie van de Vlaamse Gemeenchap, Caixa de Balears, 1994, pp. 13-17.

VAN NIEUWENBORGH, M.: "Masereel is in China ongewoon aktueel". Standard, 27 de agosto de 1989 .

VAN PARIJS, J.: Masereel, een biografie. Amberes, Houtekiet, 1995.

VAN PARYS, J. "Frans Masereel in Moskou”. Nieuw Wereldtijdschrift, n. ${ }^{\circ}$ 5, 1994, pp. 4-11.

VERHAEREN, E.: Cinq récits ilustrés de bois de Masereel. Bruselas, Le vice impuni, Editorial Jacques Antoine, 1985

VERHAEREN, É.; REGOYOS, D. de: España Negra. Madrid, Taurus Ediciones, 1963.

VILABELLA, J. M.: Humor gráfico asturiano. Oviedo, Servicio de Publicaciones, Caja de Ahorros de Asturias, 1987.

ZABALBESCOA, A.: "Leer la ciudad". Diario El País. Del tirador a la ciudad, 23 de marzo de 2012. https://elpais.com/elpais/2012/03/23/del_tirador_a_la_ciudad/1332484800_133248. htm. [Consultado el 18/06/2020]. 